EPA/600/R-08/023

October 2007

\title{
Converting Limbo Lands to Energy-Generating Stations: Renewable Energy Technologies on Underused, Formerly Contaminated Sites
}

By:

Gail Mosey, Donna Heimiller, Douglas Dahle, Laura Vimmerstedt, and Liz Brady-Sabeff

National Renewable Energy Laboratory

1617 Cole Blvd.

Golden, CO 80401

Under Contract No. DE-AC36-99-GO10337

Through EPA IAG NO. DW89930254010

NREL/TP-640-41522

For:

George Huffman, EPA Project Manager

Sustainable Technology Division

National Risk Management Research Laboratory

U.S. Environmental Protection Agency

Cincinnati, Ohio 45268

National Risk Management Research Laboratory

Office of Research and Development

U.S. Environmental Protection Agency

Cincinnati, Ohio 45268 


\section{Notice}

The U.S. Environmental Protection Agency through its Office of Research and Development funded the research described here under IAG DW89939897-01-0 through the U.S. Department of Energy (DOE) Contract DE-AC09-96EW96405. It has been subjected to the Agency's peer and administrative review and has been cleared for publication as an EPA document. Reference herein to any specific commercial product, process, or service by trade name, trademark, manufacturer, or otherwise, does not necessarily constitute or imply its endorsement or recommendation. The views and opinions of authors expressed herein do not necessarily state or reflect those of the EPA or DOE, or any agency thereof. 


\section{Foreword}

The U.S. Environmental Protection Agency is charged by Congress with protecting the Nation's land, air, and water resources. Under a mandate of national environmental laws, the Agency strives to formulate and implement actions leading to a compatible balance between human activities and the ability of natural systems to support and nurture life. To meet this mandate, EPA's research program is providing data and technical support for solving environmental problems today and building a science knowledge base necessary to manage our ecological resources wisely, understand how pollutants affect our health, and prevent or reduce environmental risks in the future.

The National Risk Management Research Laboratory is the Agency's center for investigation of technological and management approaches for preventing and reducing risks from pollution that threatens human health and the environment. The focus of the Laboratory's research program is on methods and their cost effectiveness for prevention and control of pollution to air, land, water, and subsurface resources; protection of water quality in public water systems; remediation of contaminated sites, sediments, and groundwater; prevention and control of indoor air pollution; and restoration of ecosystems. The NRMRL collaborates with both public and private-sector partners to foster technologies that reduce the cost of compliance and to anticipate emerging problems. NRMRL's research provides solutions to environmental problems by developing and promoting technologies that protect and improve the environment; advancing scientific and engineering information to support regulatory and policy decisions; and providing the technical support and information transfer to ensure implementation of environmental regulations and strategies at the national, state, and community levels.

This publication has been produced as part of the Laboratory's strategic long-term research plan. It is published and made available by EPA's Office of Research and Development to assist the user community and to link researchers with their clients.

Sally Gutierrez, Director

National Risk Management Research Laboratory 


\begin{abstract}
This report addresses the potential for using "Limbo Lands" as sites for renewable energy generating stations. Limbo Lands are considered as underused, formerly contaminated sites, and include former Superfund sites, landfills, brownfields, abandoned mine lands, former industrial sites, and certain government installations.

The National Renewable Energy Laboratory (NREL) conducted this study for the U.S. Environmental Protection Agency (EPA), National Risk Management Research Laboratory, Sustainable Technology Division (NRMRL-STD). The objective of this report, which provides a geographic screening of potential sites, is to address Limbo Lands that are ready for redevelopment and their feasibility with renewable energy technologies (RETs).

The report discusses reasons for considering RETs (and which ones) as a redevelopment option on Limbo Lands, describes the geographic screening process, identifies high-potential limbo land sites for RET redevelopment, includes discussion of two specific types of Limbo Lands: brownfields and abandoned mine lands, and provides conclusions and recommendations.
\end{abstract}




\section{Contents}

Notice

Foreword

iii

Abstract

iv

Contents

Figures

V

Tables

vi

Acronyms

viii

Acknowledgments

ix

$\mathrm{X}$

1.0 Introduction 1

1.1 NREL Experience in Renewable Energy Site Evaluation 2

1.2 Report Organization

2.0 Reasons for Considering RETs as a Redevelopment Option on Limbo Lands 3

3.0 Process for Geographic Screening of Limbo Lands to Identify

High-Potential Sites for Redevelopment with RETs

3.1 Limbo Lands Under Consideration in this Report 4

3.2 Site Readiness for Redevelopment 4

3.3 Application of Land-Use Exclusions 6

4.0 Identification of High-Potential Limbo Lands for Redevelopment Using RETs

4.1 Wind Power Considerations and Resource Availability 7

4.1.1 Land Exclusions for Wind $\quad 8$

4.1.2 Screening Criteria for Wind 8

4.1.3 Large-Wind RET High-Potential Site Identification 9

4.1.4 Small-Wind RET High-Potential Site Identification 11

4.2 Solar Power 13

4.2.1 CSP Resource Availability 13

4.2.2 CSP RET High-Potential Site Identification 14

4.2.3 Photovoltaic Resource 16

4.2.4 PV RET High-Potential Sites 16

$\begin{array}{ll}4.3 \text { Biomass } & 17\end{array}$

4.3.1 Growing Biomass $\quad 17$

4.3.2 Producing Ethanol with a Dry Mill Corn Ethanol Plant $\quad 18$

$\begin{array}{ll}\text { 4.3.3 Generating Biopower } & 18\end{array}$

4.3.4 Screening Criteria for Biomass 19

4.3.5 Growing Corn as a Feedstock for Dry Mill Corn Ethanol Plant High-Potential Sites 20

4.3.6 Dry Mill Corn Ethanol Plant or Biopower Plant

High-Potential Sites $\quad 22$ 


\section{Contents (cont'd)}

5.0 Other Types of Limbo Lands - Brownfields and Abandoned Mine Lands 24 $\begin{array}{ll}5.1 \text { Brownfields } & 24\end{array}$

5.1.1 Florida Brownfields $\quad 25$

5.1.2 PV in Florida $\quad 26$

5.1.3 Biomass in Florida $\quad 27$

5.2 Abandoned Mine Lands 30

6.0 Recommendations and Conclusions 31

Appendix A - An Assessment of RET Potential at a Former Mine in

Beatty, Nevada $\quad 32$

Appendix B - PV and CSP Screening Criteria for BLM and USFS

Evaluation by NREL $\quad 34$

Appendix C - Wind Screening Criteria for Evaluation for BLM and USFS

by NREL 35

\section{Figures}

Figure 1: Map of sites listed as "construction complete" or "deleted" in the NPL as of July 15, 2005

Figure 2: Map of sites that meet land exclusions bulleted under Section $3.3 \quad 7$

$\begin{array}{lr}\text { Figure 3: Wind resource map } & 8\end{array}$

Figure 4: Sites that meet preliminary screening criteria for large wind $\quad 10$

$\begin{array}{lr}\text { Figure 5: Final large wind sites } & 10\end{array}$

Figure 6: Sites that meet preliminary screening criteria for small wind 11

$\begin{array}{lr}\text { Figure 7: Final sites for small wind } & 12\end{array}$

Figure 8: Concentrating solar power (CSP) resource availability 13

Figure 9: Sites that meet preliminary screening criteria for CSP 15 


\section{Figures (cont'd)}

Figure 10: Final sites for CSP

Figure 11: Photovoltaic (PV) resource availability with potential sites

Figure 12: Biomass crop residues availability, with ethanol biorefineries and biopower plants that exist or are under construction

Figure 13: All biomass residue resource availability, with biorefineries and biopower plants that exist or are under construction

Figure 14: Sites that meet preliminary screening criteria for growing corn as a feedstock for biofuels, with biorefineries that exist or are under construction

Figure 15: Final sites for growing corn as a feedstock for biofuels, with biorefineries that exist or are under construction

Figure 16: Sites remaining after applying preliminary screening criteria for dry mill corn ethanol and biopower plants, with biorefinery and biopower plants that exist or are under construction

Figure 17: Final sites for dry mill corn ethanol and/or biopower plants, with biorefinery and biopower plants that exist or are under construction

Figure 18: Brownfields in Florida

Figure 19: PV resource availability in Florida, with all brownfield sites

Figure 20: Agricultural biomass resource availability in Florida, with all brownfield sites

Figure 21: Biomass residue availability of all residues in Florida, with all brownfield sites

Figure 22: High-potential brownfields for biopower plant and dry mill corn ethanol plant

Figure 23: Abandoned mine land (AML) locations 


\section{Tables}

Table 3: Land Considerations and Screening Criteria for Siting Biomass Operations on Limbo Lands

Table B-1: Screening Screening Criteria Developed by NREL for PV and CSP Resources for Evaluations Conducted on Behalf of BLM and USFS

Table C-1: Screening Criteria Developed by NREL for Wind Resource for Evaluations Conducted on Behalf of BLM and USFS 


\section{Acronyms and Abbreviations}

AML - abandoned mine land

BLM - Bureau of Land Management

CERCLA - Comprehensive Environmental Response, Compensation, and Liability Act

CERCLIS - Comprehensive Environmental Response, Compensation, and Liability Information System

CSP - concentrating solar power

DOD - (U.S.) Department of Defense

DOE - (U.S.) Department of Energy

DOI-OSM - Department of Interior's Office of Surface Mining

EPA - Environmental Protection Agency

GAP - Gap Analysis Program

GIS - Geographic Information Systems

NPL - National Priority List

NREL - National Renewable Energy Laboratory

NRMRL-STD - National Risk Management Research Laboratory, Sustainable Technology Division

OSWER - Office of Solid Waste and Emergency Response

PV - photovoltaics

RETs - renewable energy technologies

USFS - U.S. Forest Service 


\section{Acknowledgments}

This document was prepared by the National Renewable Energy Laboratory (NREL) for the U.S. Environmental Protection Agency's (EPA) National Risk Management Research Laboratory, Sustainable Technologies Division (NRML-STD). Gail Mosey would like to thank Michelle Kubik for her editing contribution. 


\subsection{Introduction}

The National Renewable Energy Laboratory (NREL) conducted this study for the U.S. Environmental Protection Agency (EPA), National Risk Management Research Laboratory, Sustainable Technology Division (NRMRL-STD), to address the potential for using "Limbo Lands" as sites for renewable energy generating stations. Limbo Lands are considered as underused, formerly contaminated sites, and include former Superfund sites, landfills, brownfields, ${ }^{1}$ abandoned mine lands, former industrial sites, and certain government installations.

NRMRL-STD seeks to advance the use of renewable energy and energy-efficient technologies on Limbo Lands. Their goals include advancing cleaner technologies, reducing the environmental impacts of energy systems, and improving management of environmentally challenging lands. To support these goals, NRMRL-STD has selected energy-related development of environmentally challenging sites as a priority topic for investigation. Potential environmental benefits can include less waste, emissions, and depletion of fossil fuels; advancement of clean and high efficiency technology; and more efficient land use.

The objective of this report, which provides a geographic screening of potential sites, is to address Limbo Lands that are ready for redevelopment and their feasibility with renewable energy technologies (RETs). This can be determined by resource availability, land-use criteria, and access to other infrastructure (e.g., roads, transmission lines). Further technical and financial analysis of these preliminarily selected sites will be needed to determine the optimal sites for development of projects.

There are many issues that must be addressed when considering renewable energy as a redevelopment option, and appropriate resource siting is only one. The decision to site RETs on Limbo Lands does not necessarily address the entire redevelopment issue. Other issues not considered in this report include reasons for a renewable energy developer to choose a Limbo Land site, ownership of the site, societal advantages, and the availability or lack of incentives for the developer.

Various types of RETs can be considered as viable options for redevelopment of Limbo Lands. The RETs ${ }^{2}$ considered here generally meet the criteria of being cost-competitive. These technologies include:

\footnotetext{
${ }^{1}$ EPA states that, “...brownfield site means real property, the expansion, redevelopment, or reuse of which may be complicated by the presence or potential presence of a hazardous substance, pollutant, or contaminant." Definition Source: The Brownfields Site definition is found in Public Law 107-118 (H.R. 2869) - "Small Business Liability Relief and Brownfields Revitalization Act" signed into law January 11, 2002.

${ }^{2}$ For additional information about each RET, see www.nrel.gov.
} 
- Wind, including small ${ }^{3}$ and large wind, ${ }^{4}$

- Solar power technologies, including concentrating solar power (CSP) and photovoltaics (PV), and

- Biomass, including growing biomass, a biofuels plant, and a biopower plant.

\subsection{NREL Experience in Renewable Energy Site Evaluation}

NREL has conducted - or is now conducting - several evaluations of lands most suitable for select RETs, such as wind and solar. These projects have given NREL the opportunity to develop a methodology to identify the sites with the greatest RET potential. The screening criteria to identify top sites, developed through NREL's experience, provide a foundation for the criteria used to assess RETs and their potential in Limbo Lands redevelopment.

NREL recently supported the evaluation of a former mine site in Beatty, Nevada. Further discussion of this evaluation can be found in Appendix A.

With respect to full-scale assessment of opportunities for siting renewable energy on federal lands, NREL has performed renewable energy evaluations for the Bureau of Land Management ${ }^{5}$ (BLM) and the U.S. Forest Service ${ }^{6}$ (USFS), and has evaluation projects underway for the U.S. Department of Defense (DOD) and the U.S. Department of Energy (DOE). For each of these evaluations, NREL worked with the agencies sponsoring the assessment to develop criteria for selecting the most desirable land areas for potential renewable energy project development. These criteria are presented in Appendices B and C. The goal of these evaluations was not to locate sites for specific projects, but rather to provide federal land managers with an understanding of the renewable resource on their lands, and to highlight regions with highest potential for near-term development, as well as long-term management strategies. Some of these strategies have included successful promotion of appropriate federal lands as renewable energy project sites.

\subsection{Report Organization}

This report is organized into six sections. Section 2 discusses reasons for considering RETs as a redevelopment option on Limbo Lands, and the RETs under consideration in this report.

Section 3 describes the geographic screening process. Section 4 identifies high-potential Limbo Land sites for RET redevelopment. Section 5 addresses two specific types of Limbo Lands: brownfields and abandoned mine lands. Section 6 includes conclusions and recommendations.

\footnotetext{
${ }^{3}$ Small wind uses Class 3 wind, which has a wind power of $300-400 \mathrm{~W} / \mathrm{m}^{2}$, wind speed at $50 \mathrm{~m}$ of $6.4-7.0 \mathrm{~m} / \mathrm{s}$ or $14.3-15.7 \mathrm{mph}$.

${ }^{4}$ Large wind uses Class 4 wind and greater, which has a wind power of at least $400 \mathrm{~W} / \mathrm{m}^{2}$, wind speed at $50 \mathrm{~m}$ of at least $7.0 \mathrm{~m} / \mathrm{s}$ or $15.7 \mathrm{mph}$.

5 “Assessing the Potential for Renewable Energy on Public Lands." (2003). 95 pp.; NREL Report No. TP-55033530; DOE/GO-102003-1704. http://www.nrel.gov/docs/fy03osti/33530.pdf

6 "Assessing the Potential for Renewable Energy on National Forest System Lands. “ (2005). 124pp.; NREL Report No. BK-710-36759. http://www.nrel.gov/docs/fy05osti/36759.pdf
} 


\subsection{Reasons for Considering RETs as a Redevelopment Option on Limbo Lands}

The development of Limbo Lands comes with a variety of goals, and the reasons for considering RETs as a redevelopment option are discussed here. EPA's Office of Solid Waste and Emergency Response (OSWER) states $^{7}$ the reasoning behind citing energy-generating facilities on revitalized lands as follows:

"Revitalized properties present opportunities for meeting the land needs of the hundreds of new energy facilities anticipated to be developed in the coming decades. Through focused site screening and identification, interagency coordination, and partnerships with the utility sector and communities, EPA OSWER can help restore contaminated lands while helping to further domestic energy security."

RETs, in particular, may be considered for reuse applications. EPA OSWER further states that reasons ${ }^{8}$ for pursuing renewable energy projects may include:

- Taking stress off undeveloped lands (greenfields) for construction of new energy facilities;

- Using existing transmission capacity and infrastructure of formerly developed lands;

- Providing economically viable reuse to sites with significant cleanup costs or low real estate development demand; and

- Spurring needed investment in both urban and rural communities, and creating jobs.

\subsection{Process for Geographic Screening of Limbo Lands to Identify High-Potential Sites for Redevelopment with RETs}

The geographic screening for identifying Limbo Land redevelopment using RETs is a multistage process and depends, to some extent, on the renewable energy resource being considered. It generally follows the process outlined below.

- Stage I: Identify initial sites for screening process. The first stage is to identify Limbo Lands for further screening, whether they are former Superfund sites, abandoned mine lands, brownfields, or some other type of Limbo Land. The sites are then mapped using Geographic Information Systems (GIS). Ideally, for optimal site identification, data for each site would include GIS coordinates (or data that can be translated into coordinates such as latitude and longitude or address), parcel size, and some indication of the status of cleanup at the site.

- Stage II: Eliminate sites based on land exclusions, then on minimum parcel size. The next stage is to exclude sites that are located in areas that would preclude redevelopment such as wetlands, national parks, and national conservation areas. The

\footnotetext{
${ }^{7}$ Domestic Energy Development on Revitalized Lands, Ed Chu, EPA OSWER, Draft - December 2005.

${ }^{8}$ Ibid.
} 
sites that remain after land-use exclusions are screened for parcel size because most RETs considered here require a minimum size to be viable.

- Stage III: Consider the renewable energy resource and the remaining RET-specific screening criteria and identify high-potential sites. Limbo Lands that remain after applying land exclusions and minimum parcel size evaluations are screened for quality of the renewable resource and infrastructure considerations.

\subsection{Limbo Lands under Consideration in this Report}

To determine potential Limbo Lands for RET redevelopment, a data source is necessary to identify initial sites for further screening. Ideal information for mapping and screening the sites are geographic coordinates such as latitude and longitude, parcel size, and status of cleanup. Status of cleanup is an important factor for this screening because this report considers only lands that are ready or nearly ready for redevelopment.

This study uses the National Priority List (NPL), ${ }^{9}$ developed and maintained by the EPA. EPA describes the NPL as, “...the list of national priorities among the known releases or threatened releases of hazardous substances, pollutants, or contaminants throughout the United States and its territories. The NPL is intended primarily to guide the EPA in determining which sites warrant further investigation."10 The NPL includes the necessary information for mapping and screening the sites: geographic coordinates of latitude and longitude, parcel size, and NPL status, which is an indication of readiness for reuse. Data from the NPL can be accessed through the Comprehensive Environmental Response, Compensation, and Liability Information System (CERCLIS) database in the Envirofacts Data Warehouse sponsored by EPA.

\subsection{Site Readiness for Redevelopment}

For purposes of this screening, we consider sites in the NPL that are classified as "Construction Complete" or "Deleted" because these sites are generally ready for redevelopment. Sites qualify for Construction Complete ${ }^{11}$ when any necessary physical construction is complete or EPA has determined that reuse should not involve construction, or the site qualifies for deletion (but has not yet gone through the process of being deleted) from the NPL. Those sites identified as Construction Complete in this study that have not met final cleanup levels, or that have restrictions on construction, may need to be further reviewed for feasibility if they are being considered for redevelopment with renewable energy power generation. Sites qualify for

\footnotetext{
${ }^{9}$ July 2005 version is used for this report.

${ }^{10} \mathrm{http}: / / w w w . e p a . g o v /$ superfund/sites/npl/index.htm

${ }^{11}$ EPA has developed the construction completions list (CCL) to simplify its system of categorizing sites and to better communicate the successful completion of cleanup activities. Sites qualify when any necessary physical construction is complete, whether or not final cleanup levels or other requirements have been achieved; or EPA has determined that the response action should be limited to measures that do not involve construction; or the site qualifies for deletion from the NPL. Source: http://www.epa.gov/superfund/action/process/ccl.htm
} 
deletion $^{12}$ when EPA determines that no further response is required to protect human health or the environment.

There are 874 sites on the NPL that are listed as Construction Complete ( 272 sites) or Deleted (602 sites), as shown in Figure 1. These are the sites ${ }^{13}$ that are further screened in this report for suitability of including RETs as part of the redevelopment strategy.

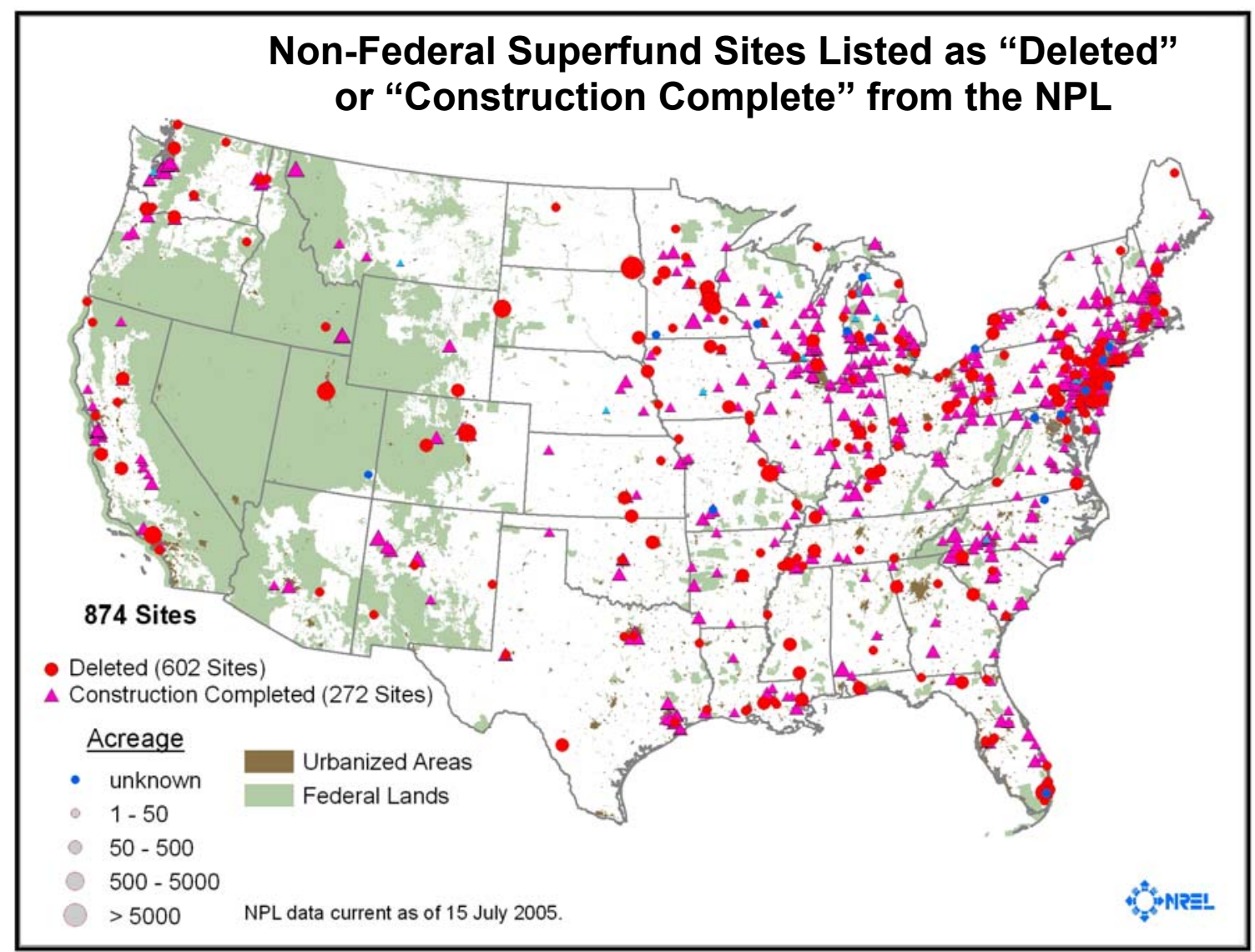

Figure 1: Map of sites listed as "construction complete" or "deleted" in the NPL as of July 15, 2005.

\footnotetext{
${ }^{12}$ EPA may delete a final NPL site if it determines that no further response is required to protect human health or the environment. Under Section 300.425(e) of the National Contingency Plan (55 FR 8845, March 8, 1990), a site may be deleted where no further response is appropriate if EPA determines that one of the following criteria has been met: EPA, in conjunction with the state, has determined that responsible or other parties have implemented all appropriate response action required; EPA, in consultation with the state, has determined that all appropriate Superfund-financed responses under the Comprehensive Environmental Response, Compensation, and Liability Act (CERCLA) have been implemented and that no further response by responsible parties is appropriate; or a Remedial Investigation/Feasibility Study has shown that the release poses no significant threat to public health or the environment and, therefore, remedial measures are not appropriate. Source:

http://www.epa.gov/superfund/programs/npl_hrs/nploff.htm

${ }^{13}$ For all sites in the NPL listed as "construction complete" or "deleted," distance to transmission breaks down as follows: $<5$ miles, 792 sites; 5-10 miles, 60 sites; $10-20$ miles, 19 sites; 20-33 miles, 3 sites. No site was greater than 33 miles from transmission. Further, it is interesting to note that all sites in the NPL were within 10 miles of a road. This becomes significant in later sections of the report when screening criteria is applied.
} 


\subsection{Application of Land-Use Exclusions}

Certain Limbo Lands are excluded due to their location in an area that makes RET redevelopment infeasible, such as urban areas for a large wind farm, or in environmentally sensitive or land-preservation areas, such as wetlands and wilderness study areas. In general, the land-use exclusions listed below are applied across all the RETs ${ }^{14}$ considered in this report:

- $100 \%$ exclusion for urban areas, airports, water, wetlands, wild and scenic rivers, and wilderness study areas.

- $100 \%$ exclusion of federal lands with any type of special designation such as national parks, national preserves, national monuments, national conservation areas, wilderness areas, etc.

- All excluded areas above, except for water bodies, are expanded by $3 \mathrm{~km}^{15}$ along their perimeter.

Seven hundred and thirty-seven sites remain for consideration after applying the land-use exclusions outlined above (see Figure 2).

\footnotetext{
${ }^{14} \mathrm{PV}$ is not limited by these exclusions because it can conceivably be placed on certain excluded lands such as in an urban setting and an airport, and could potentially be used in buildings on federal lands.

${ }^{15}$ The exception to this additional screening criterion is for growing biomass.
} 


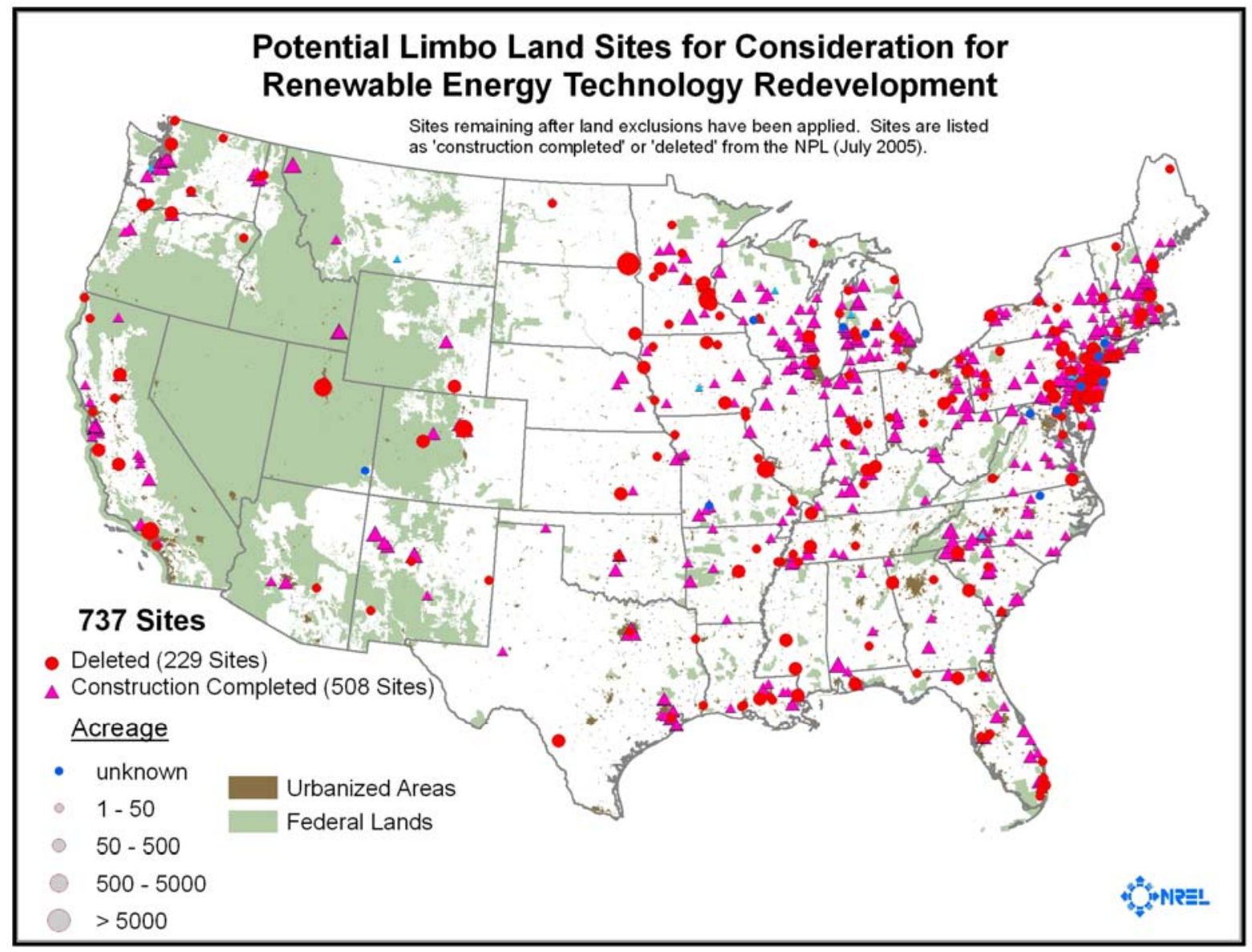

Figure 2: Map of sites that meet land exclusions bulleted under Section 3.3.

\subsection{Identification of High-Potential Limbo Lands for Redevelopment Using RETs}

RET-specific screening criteria can now be applied to those lands that meet site readiness and land-use exclusions. Identified below are high-potential sites for wind, solar, and biomass.

\subsection{Wind Power Considerations and Resource Availability}

Wind power can be well-suited to Limbo Lands, due to the widespread availability of the resource and the flexibility in the size and number of turbines that can be installed. Wind turbines can be described by the class of the resource they use to operate. Small wind turbines operate with Class 3 wind, range in size from 50 to 750 kilowatts, and are typically used for nongrid-connected, distributed generation. Large wind or utility-scale turbines use Class 4 or higher wind, typically range in size from 750 kilowatts to 2.5 megawatts, and are used for gridconnected generation. While small wind turbines theoretically could be grid-connected, and a single large wind turbine could be installed and used for remote power generation, such configurations would not be the least-cost option. For this study, we assume that small wind 
turbines are installed singly and used for remote power generation, while large wind turbines are installed in multiples and are grid-connected.

The quality of the wind resource varies across the United States. In general, the higher quality wind resource is in the western half of the United States, with some good quality resource around the northern and central Appalachian range and near the Great Lakes. A wind resource map is presented in Figure 3.

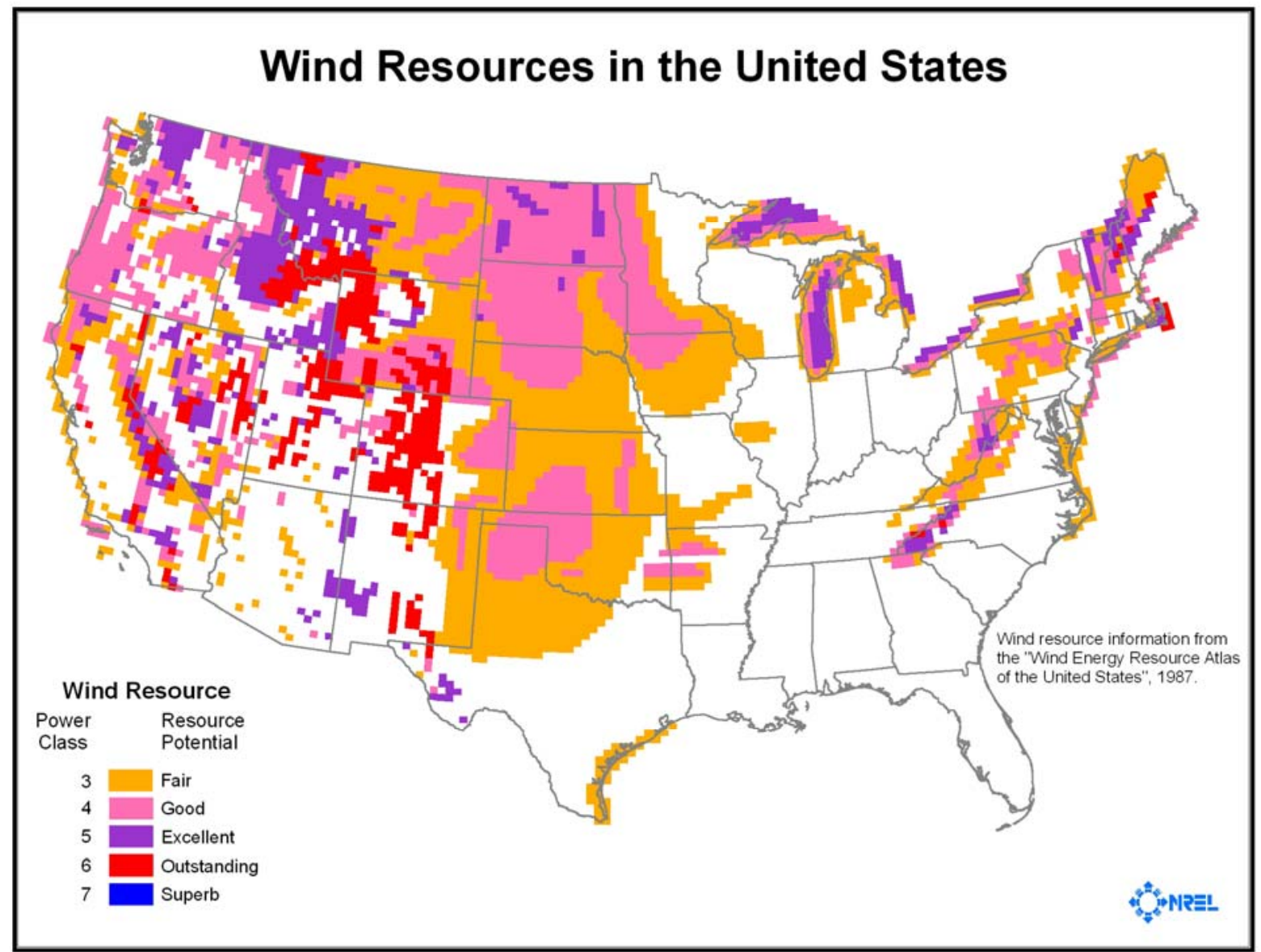

Figure 3: Wind resource map.

\subsubsection{Land Exclusions for Wind}

In addition to the above land-use exclusions, wind is also subject to a $3 \mathrm{~km}$ buffer around all excluded lands, except water bodies. Three hundred and nine sites remain for further screening once the $3 \mathrm{~km}$ buffer has been applied.

\subsubsection{Screening Criteria for Wind}

Screening criteria for small and large wind is presented in Table 1. In addition to land-use exclusions, developers need to consider parcel size, slope, resource, and distance to road and transmission. The screening criteria for small wind are somewhat less stringent than that for 
large wind, due to the intended application of the wind power for Limbo Lands redevelopment. Large wind is intended for larger-scale, grid-connected power generation applications and, thus, should have a footprint of at least 50 acres and be within 25 miles to transmission and graded roads. Small wind is intended, in this report, for remote non-grid-connected applications because it is economically feasible to install a single small-wind turbine to meet on-site power requirements. The small-wind criteria for minimum parcel size and distance to transmission and road are not strict measures; rather, they are designed as guidelines for Limbo Land sites where grid connection is infeasible due to a remote location or undesirable because the site only requires power for on-site needs. Small-wind screening may also be more uncertain than that for large wind because small wind may be impacted by microclimates that may improve or decrease the wind resource.

Table 1: Screening Criteria for Siting Wind on Limbo Lands

\begin{tabular}{|l|l|l|}
\hline Criteria & \multicolumn{1}{|c|}{ Large Wind } & \multicolumn{1}{c|}{ Small Wind } \\
\hline Land Considerations & $>=50$ acres & $>=5$ acres \\
\hline Minimum Parcel Size & $<=20 \%$ & $<=20 \%$ \\
\hline Slope & $>=$ Class 4 & $>=$ Class 3 \\
\hline Other Considerations & $<=25$ miles to $69-345 \mathrm{kV}$ lines & $>=5$ miles \\
\hline Resource & $<=25$ miles to graded road & $>=5$ miles \\
\hline Distance to Transmission &
\end{tabular}

\subsubsection{Large-Wind RET High-Potential Site Identification}

To identify those sites with the highest potential for large wind, land considerations and the remaining criteria are applied to those sites remaining after land-use exclusions have been applied. After applying minimum parcel size and minimum slope criteria, 105 sites remain, as shown in Figure 4. The remaining criteria include a minimum of Class 4 resource availability and a requirement that the site be located within 25 miles to transmission and road. Five sites meet the remaining screening criteria and can be considered as high-potential sites for large wind as shown in Figure 5. The sites include:

- Mystery Bridge, Evansville, Wyoming (Natrona County)

- Arsenic Trioxide site, cities of Lidgerwood, Wyndmere, and Rutland, North Dakota (Richland, Ransom, and Sargent counties)

- Lagrand Sanitary Landfill, Lagrand Township, Minnesota (Douglas County)

- Wide Beach Development, Brant, New York (Erie County)

- North Sea Municipal Landfill, North Sea, New York (Suffolk County). 


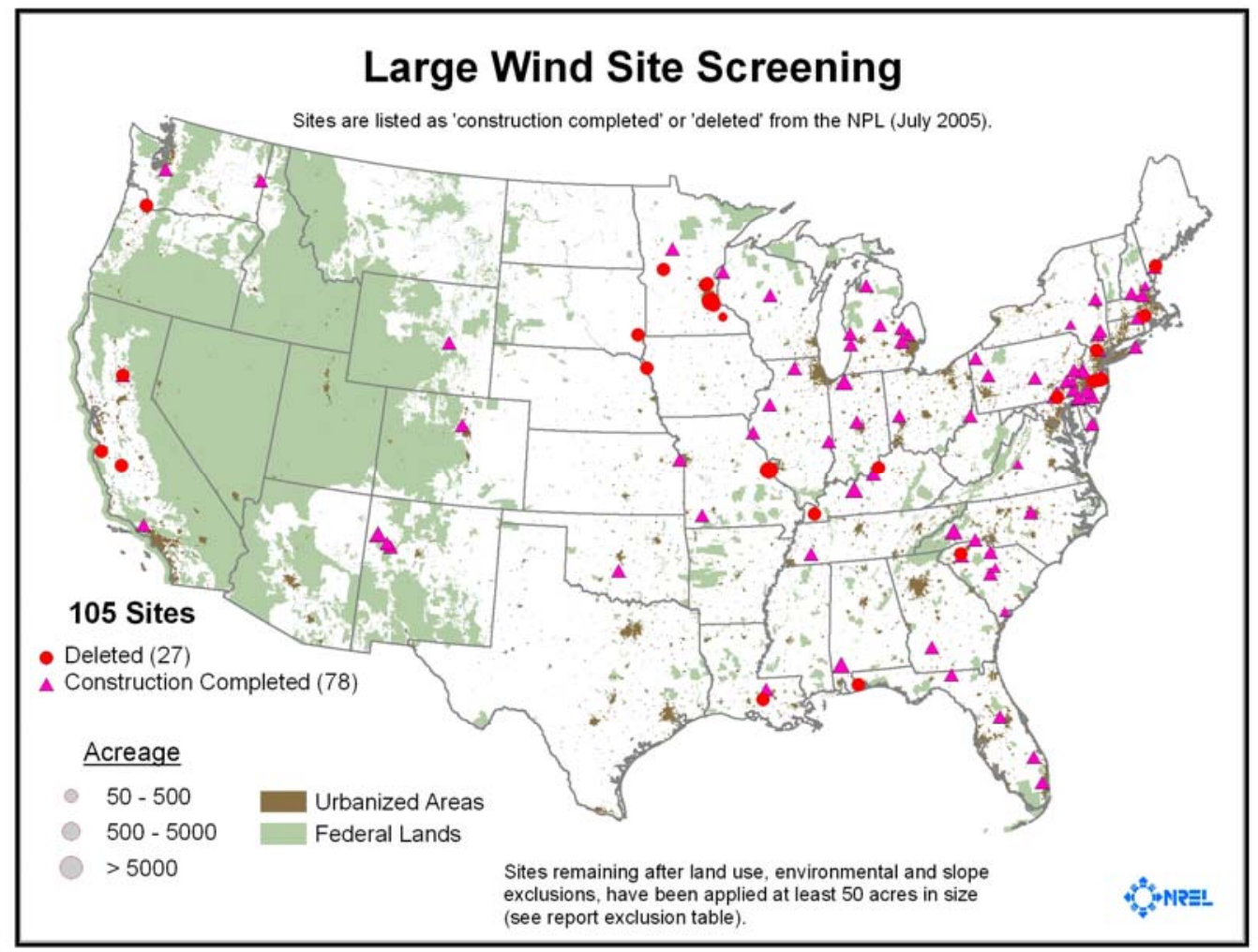

Figure 4: Sites that meet preliminary screening criteria for large wind.

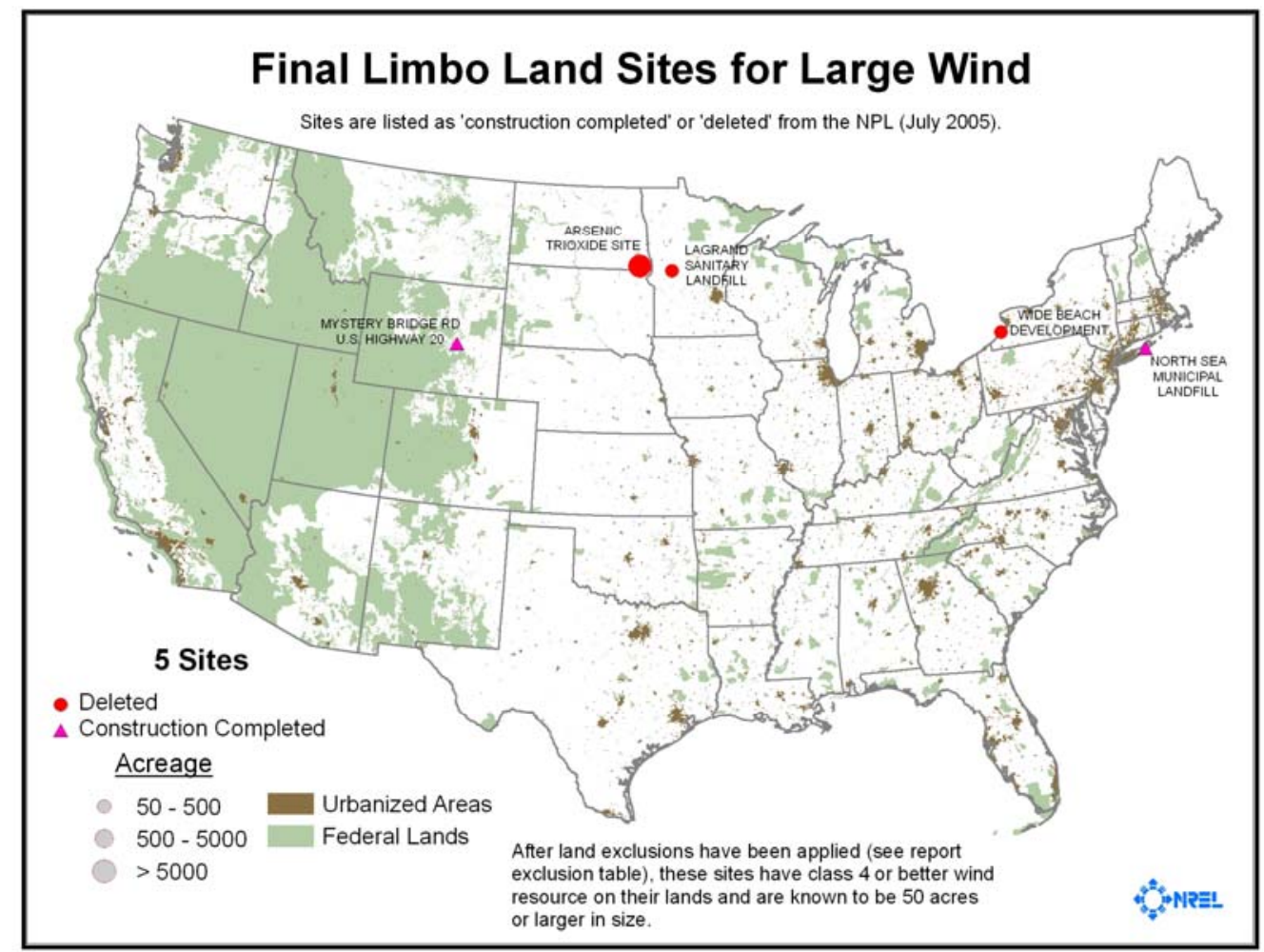

Figure 5: Final large wind sites. 


\subsubsection{Small-Wind RET High-Potential Site Identification}

The requirements for small-wind applications differ somewhat from those for large wind due to the difference in intended applications. The idea is for a smaller, non-grid-connected wind turbine to provide power generation requirements on a Limbo Land site with a small footprint that is remote enough for grid connection to be infeasible. The criteria for small wind include a parcel size of at least 5 acres and a distance greater than 5 miles from transmission lines, leaving 251 appropriate small wind sites to be screened for resource availability (Figure 6). Five additional sites remain after applying the Class 3 or greater wind resource criteria and can be considered as high-potential sites for small wind, as shown in Figure 7. The sites include:

- $\quad$ Ritari Post \& Pole, Sebeka, Minnesota (Wadena County)

- Mid-America Tanning Co, Sergeant Bluff, Iowa (Woodbury County)

- Hardage/Criner, Criner, Oklahoma (McClain County)

- Velsicol-Chemical Corporation (Marshall Plant), Marshall, Illinois (Clark County)

- Sidney Landfill, Sidney, New York (Delaware County).

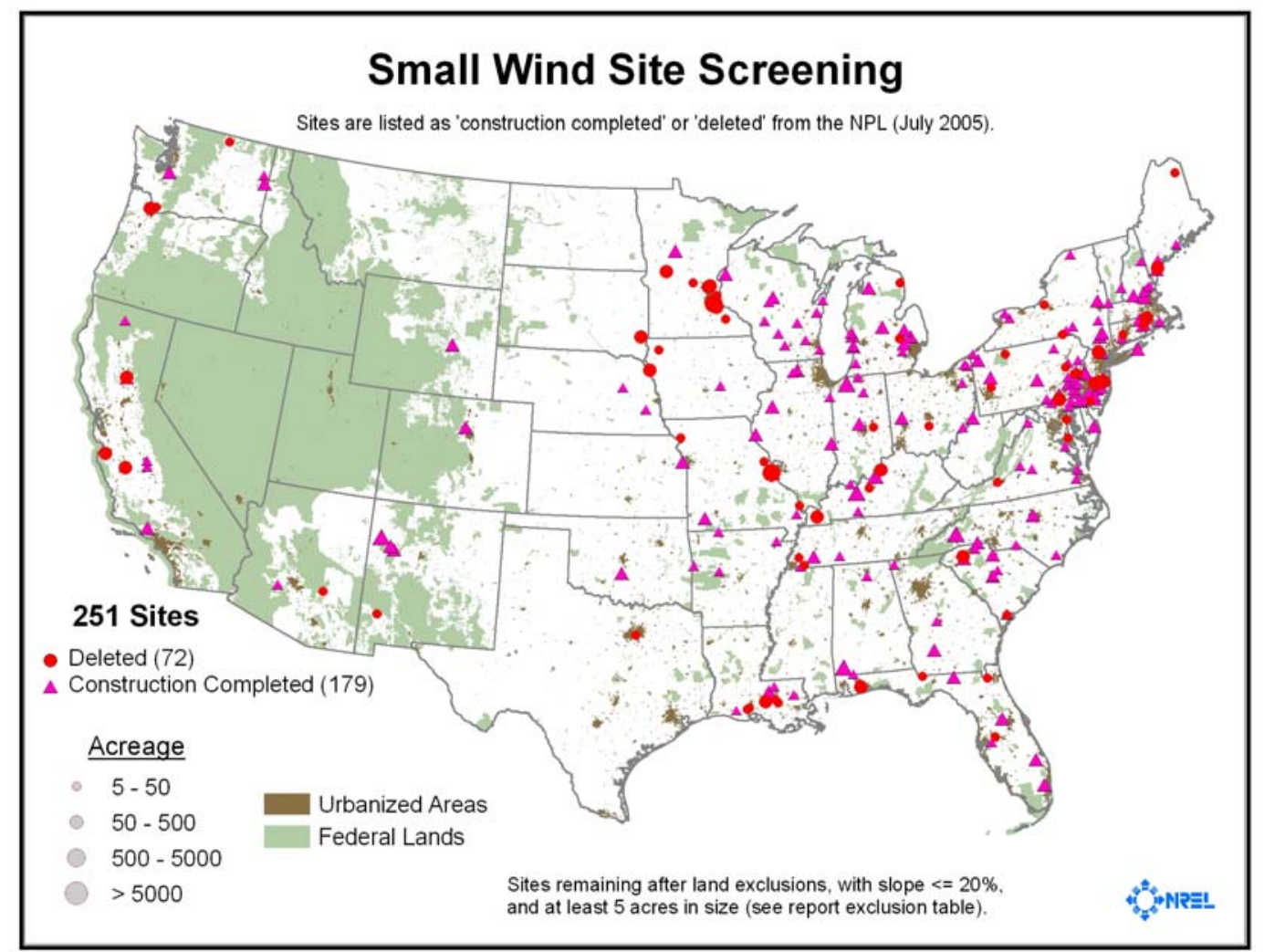

Figure 6: Sites that meet preliminary screening criteria for small wind. 


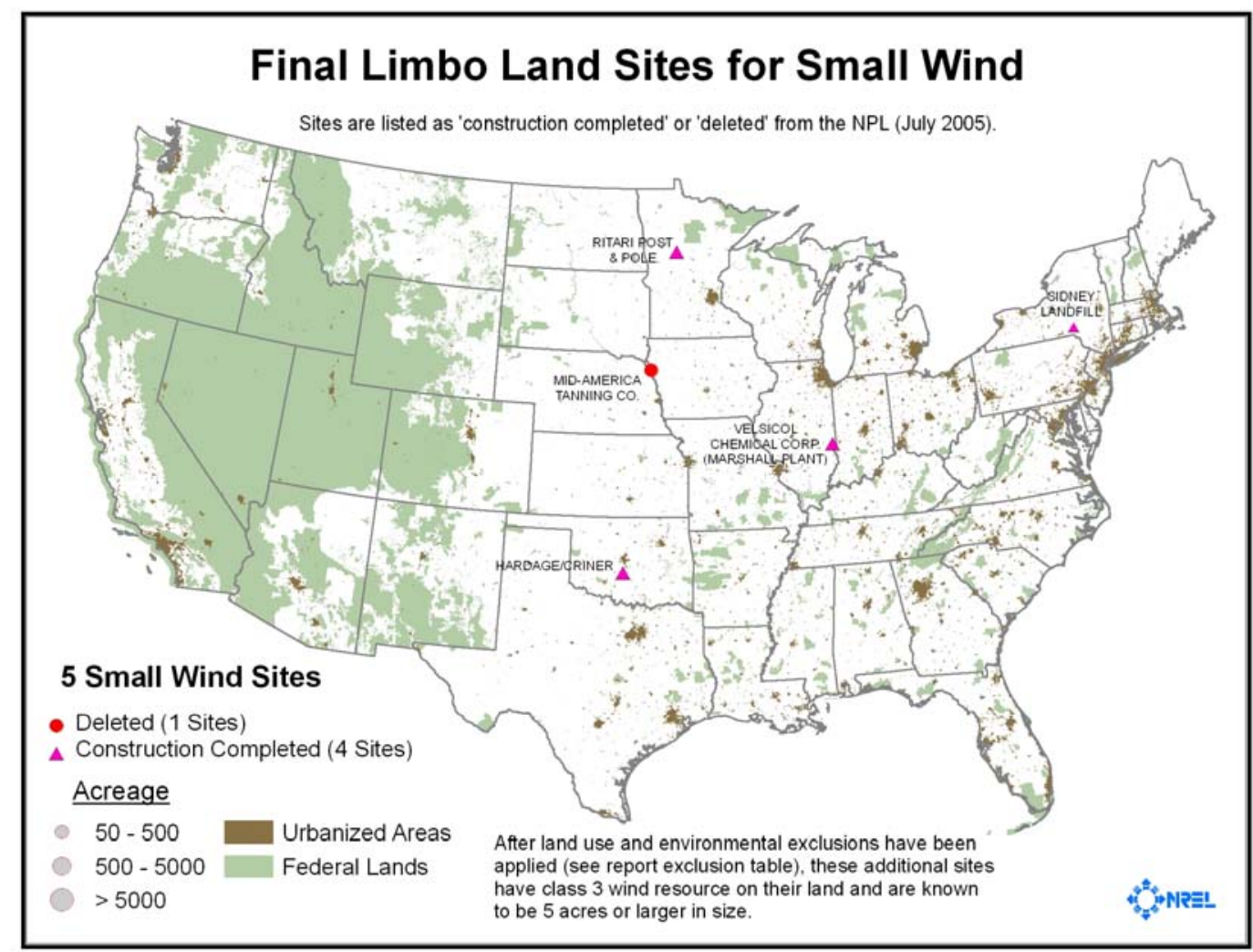

Figure 7: Final sites for small wind. 


\subsection{Solar Power}

Solar technologies are also well-suited to Limbo Land redevelopment because of the availability of quality resource. Two types of solar power that are most applicable to Limbo Lands reuse are concentrating solar power (CSP) and photovoltaics (PV).

\subsubsection{CSP Resource Availability}

Parabolic trough is the type of CSP that is most commercialized and is used for grid-connected applications, so it is well-suited to Limbo Lands that are within a reasonable distance to existing transmission and to sites that have a larger footprint to allow for a sufficient-size system for economic feasibility. As illustrated in Figure 8, the quality of the CSP resource is greatest in the southwestern United States.

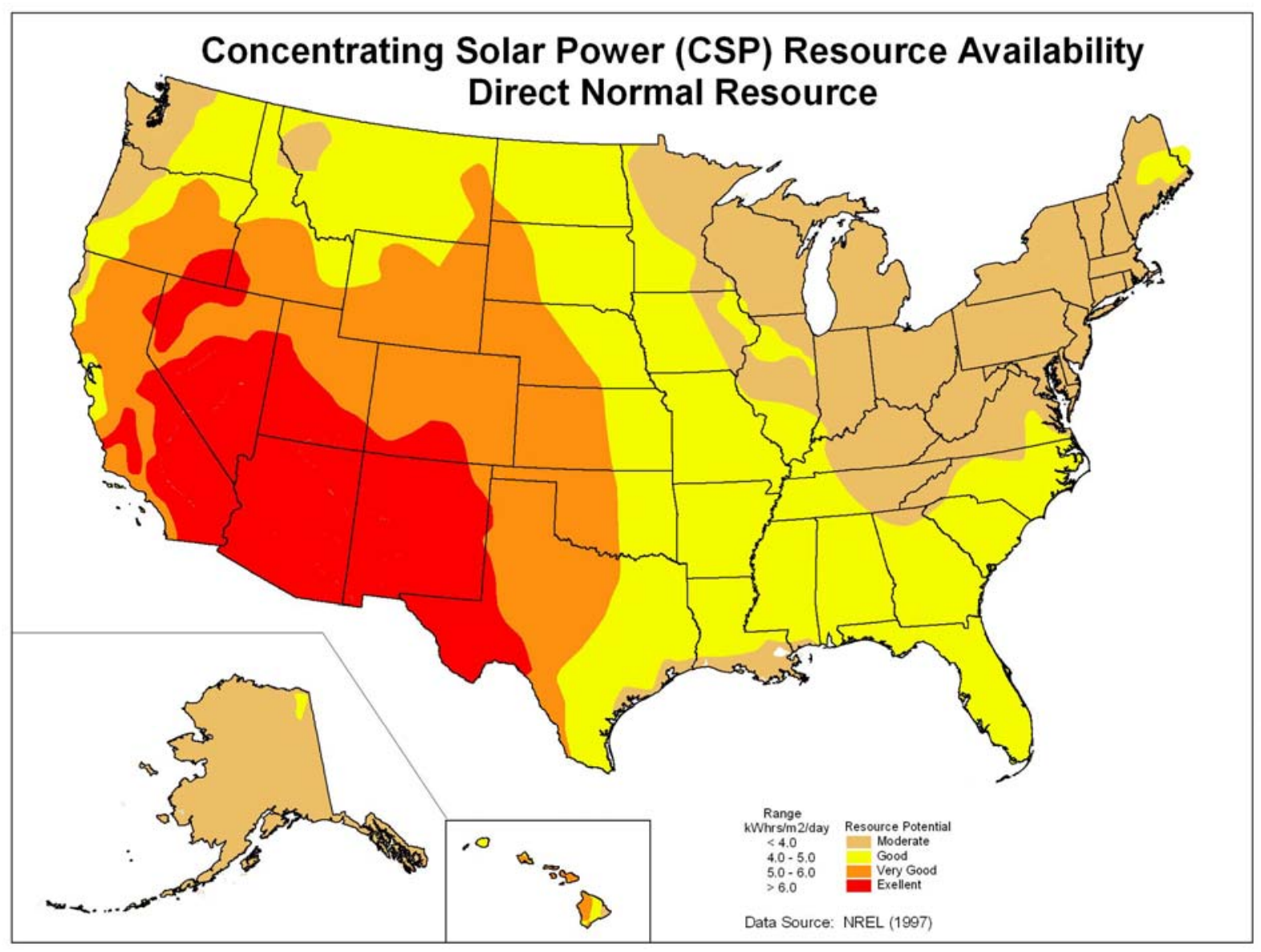

Figure 8: Concentrating solar power (CSP) resource availability. 


\subsubsection{CSP RET High-Potential Site Identification}

The screening criteria used to identify high-potential sites for CSP are presented in Table 2. These screening criteria are imposed on the sites remaining after land exclusions have been applied (Figure 2).

Table 2: Screening Criteria for Siting CSP on Limbo Lands

\begin{tabular}{|l|l|}
\hline Criteria & \multicolumn{1}{|c|}{ CSP } \\
\hline Land Considerations & $>=40$ acres \\
\hline Minimum Parcel Size & $<=1 \%$ \\
\hline Othe & $\begin{array}{l}>=6.75 \mathrm{kWh} / \mathrm{m}^{2} / \text { day annual average solar } \\
\text { irradiance (direct normal) }\end{array}$ \\
\hline Resource & $<=25$ miles to $115-345 \mathrm{kV}$ lines \\
\hline Distance to Transmission & $<=25$ miles to graded road \\
\hline Distance to Road &
\end{tabular}

Figure 9 illustrates the 210 sites that remain after land-use exclusions, minimum parcel size, and slope criteria have been applied. Once resource criteria and minimum distance to transmission and road have been considered, two sites remain and can be considered as high-potential sites for CSP (see Figure 10). The sites include:

- Homestake Mining Company, Milan, New Mexico (Cibola County)

- South Valley, Albuquerque, New Mexico (Bernalillo County). 


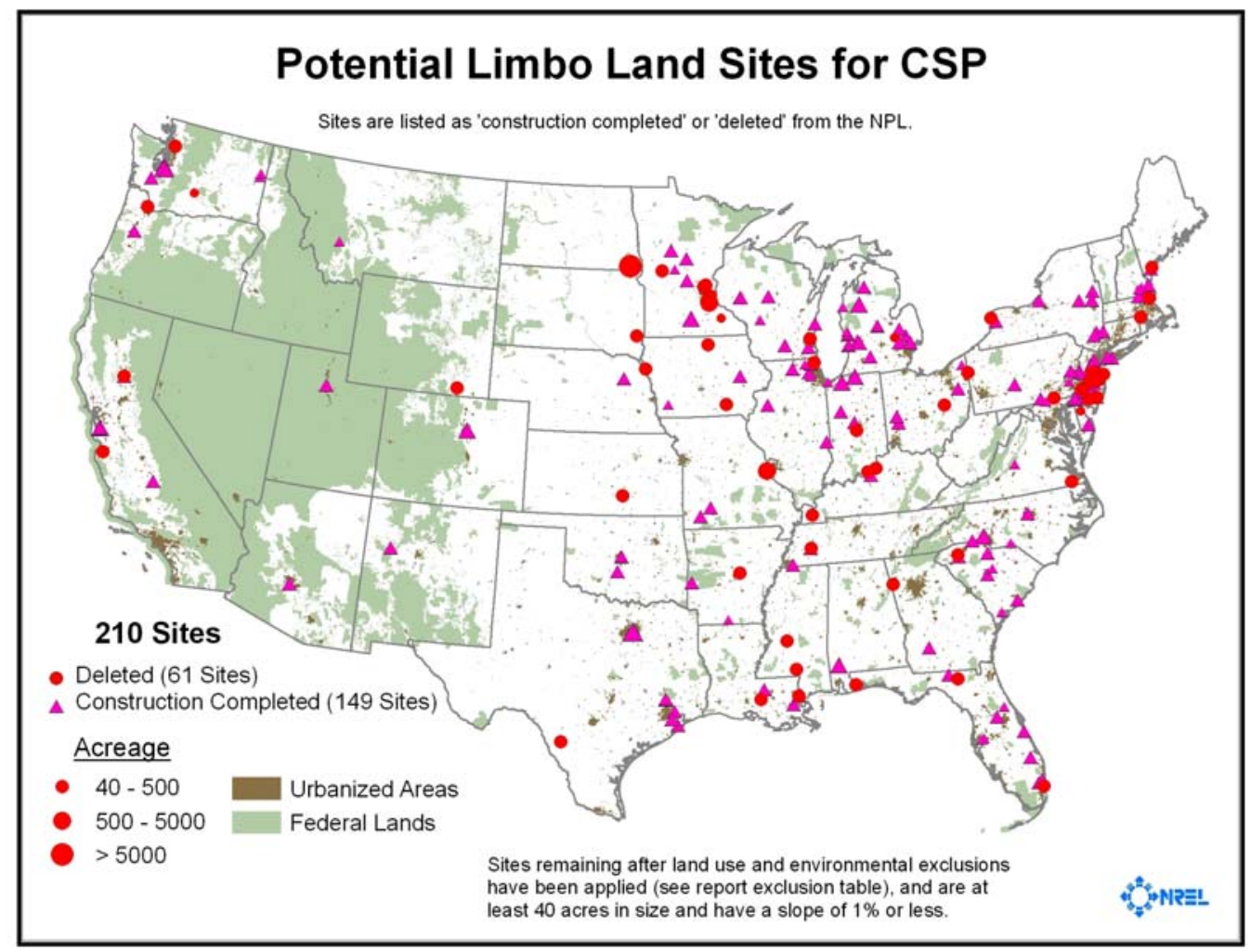

Figure 9: Sites that meet preliminary screening criteria for CSP.

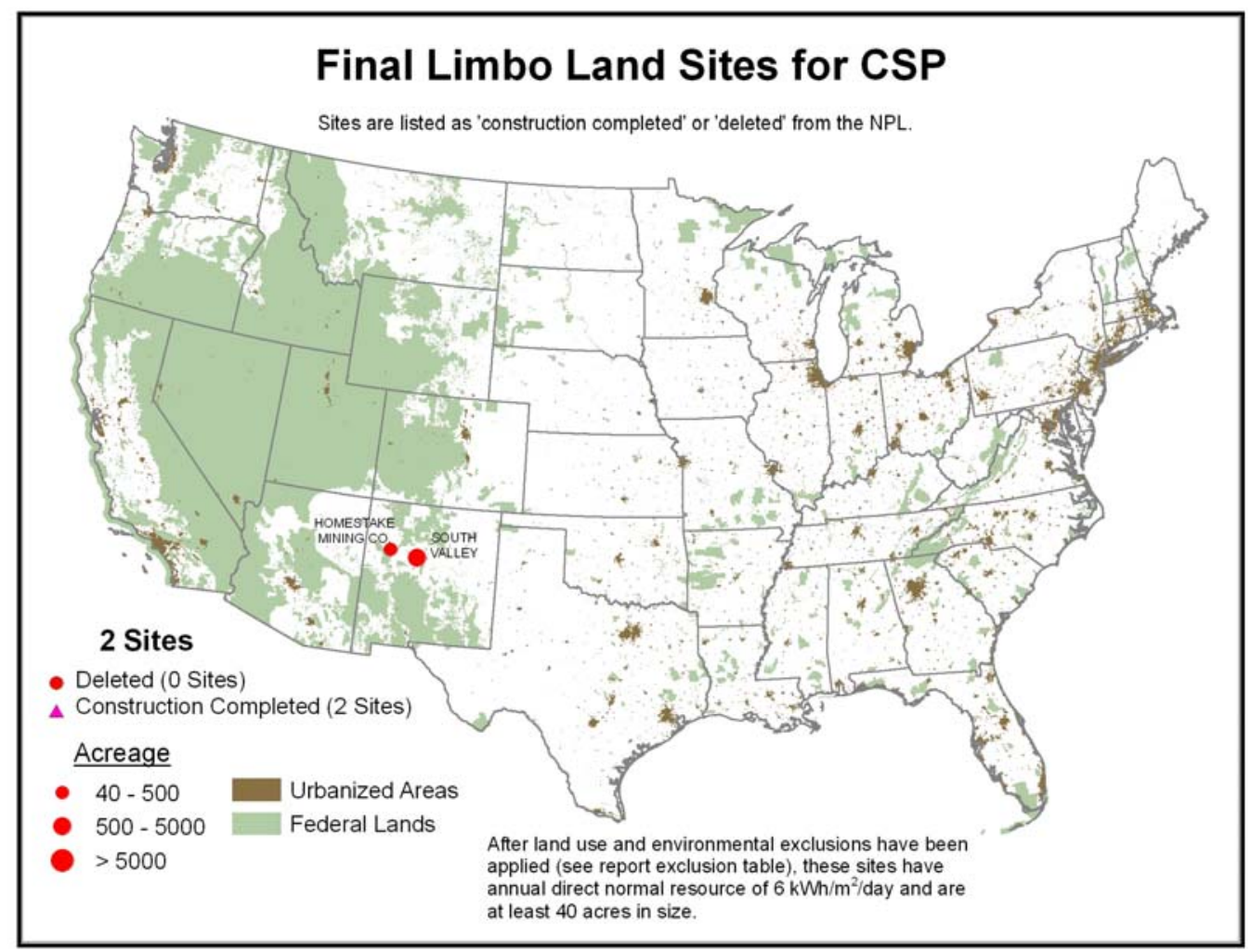

Figure 10: Final sites for CSP. 


\subsubsection{Photovoltaic Resource}

PV can be grid-connected or used for on-site power requirements. At this time, on-site PV, as compared to grid-connected PV, is the more commercialized and financially competitive option and also has flexible installment options, which make it well-suited for Limbo Land redevelopment. PV applications include providing power for lighting and smaller electricity needs, solar hot water for heating water, and solar vent preheat for preheating air coming into a building. Further, State incentives for PV system purchase and installation can make it a more financially attractive choice.

The entire United States, with the exception of a portion of the Northwest, has adequate PV resource quality (Figure 11). Thus, the decision to install a PV system depends on the power requirements at a particular site as well as site-specific economic considerations, including available incentives. On-site PV is a particularly attractive alternative for remote Limbo Lands that are in an area where grid connection is not feasible because of distance or cost.

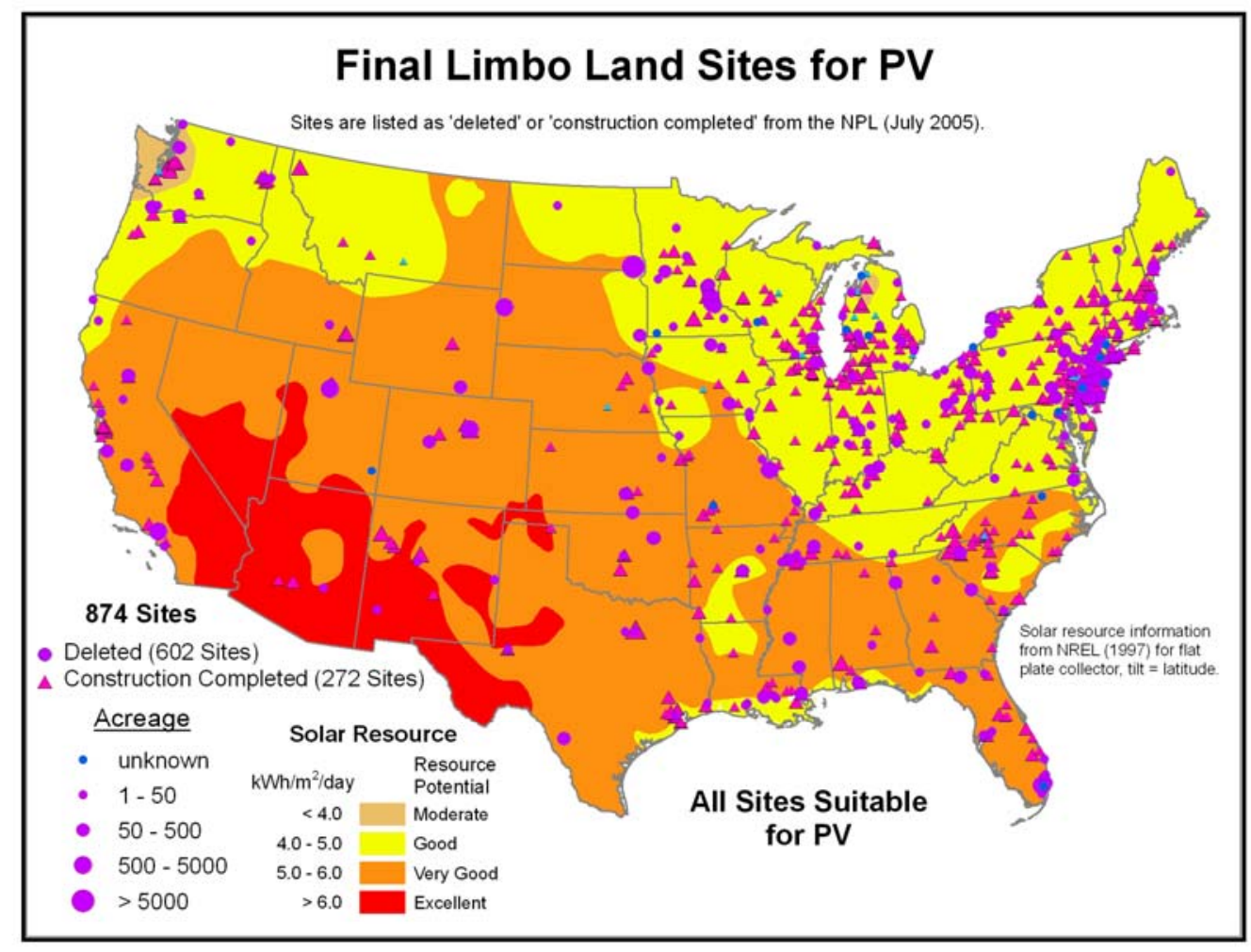

Figure 11: Photovoltaic (PV) resource availability with potential sites

\subsubsection{PV RET High-Potential Sites}

Any Limbo Land site identified in Figure 2 can conceivably be considered as a candidate for PV because the resource is adequate across most of the United States, and PV does not require grid connection. Similar to the considerations for small wind, PV is particularly well-suited to Limbo 
Land sites in remote locations where grid connection is economically infeasible due to distance to transmission; or unnecessary because the site requires only on-site power generation.

\subsection{Biomass}

Biomass is a broad category of RET with multiple applications, all of which have varying suitability to Limbo Lands. For this report, we focus on identifying sites for growing corn as a feedstock for biofuels, a dry mill corn ethanol plant, and a biopower plant.

\subsubsection{Growing Biomass}

Certain Limbo Lands may be well-suited for growing biomass to use as a feedstock for producing biofuels, which help meet transportation fuel needs. Because the most common type of biofuel for transportation is corn ethanol, this analysis identifies ideal Limbo Lands for growing corn. Figure 12, which illustrates the agricultural biomass resource availability in the United States, shows crops in addition to corn. For geographic reference, it also shows ethanol biorefineries $^{16}$ and biopower plants that exist or are under construction.

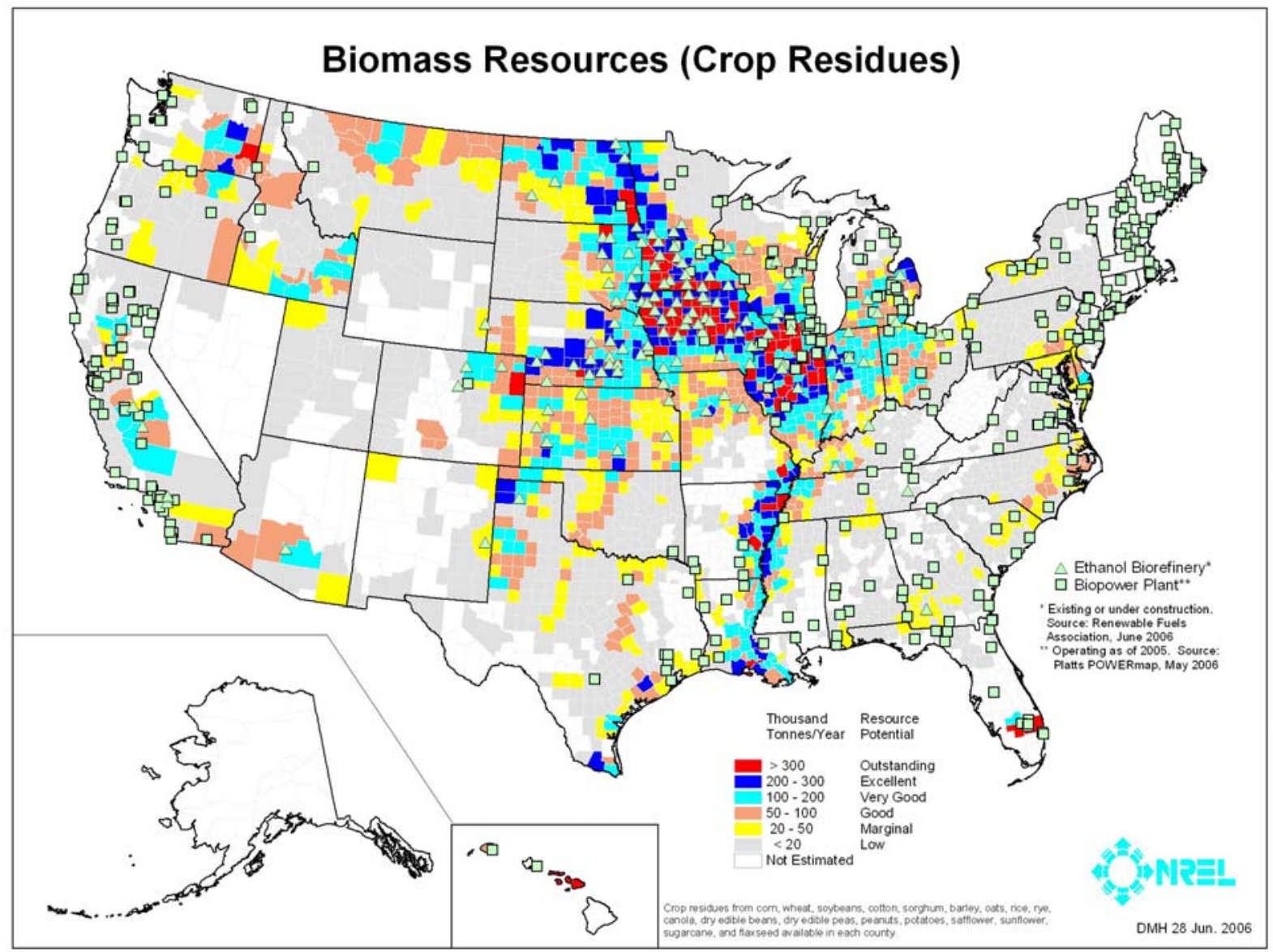

Figure 12: Biomass crop residues availability, with ethanol biorefineries and biopower plants that exist or are under construction.

\footnotetext{
${ }^{16}$ A biorefinery is a facility that integrates biomass conversion processes and equipment to produce fuels, power, and chemicals from biomass.
} 


\subsubsection{Producing Ethanol with a Dry Mill Corn Ethanol Plant}

Corn ethanol can be produced in a dry mill or wet mill facility. A wet mill facility produces products in addition to ethanol such as feed, fiber, and corn syrup, while a dry mill corn ethanol plant produces only corn ethanol. A wet mill facility tends to be more expensive and complex to construct and operate than a dry mill plant; thus, a dry mill corn ethanol plant is considered here as a potential RET for Limbo Lands. The crop residue resource availability, as shown in Figure 12, is relevant to producing ethanol from corn because these plants typically gather corn as a feedstock from within a 50-mile radius.

\subsubsection{Generating Biopower}

Biopower uses biomass to generate electricity through biopower plants, which use direct-fired systems to burn bioenergy feedstocks to produce steam. Feedstock for power generation can include urban waste, agricultural, and forestry sources. Figure 13 illustrates the biomass resource in the United States, including all residues ${ }^{17}$ that can be used for feedstock (not only agricultural), as well as ethanol biorefineries and biopower plants that exist or are under construction.

\footnotetext{
${ }^{17}$ All residues include agricultural residues (crops and animal manure); wood residues (forest, primary mill, secondary mill, and urban wood); municipal discards (methane emissions from landfills and domestic wastewater treatment); and dedicated energy crops (on Conservation Reserve Program Lands).
} 


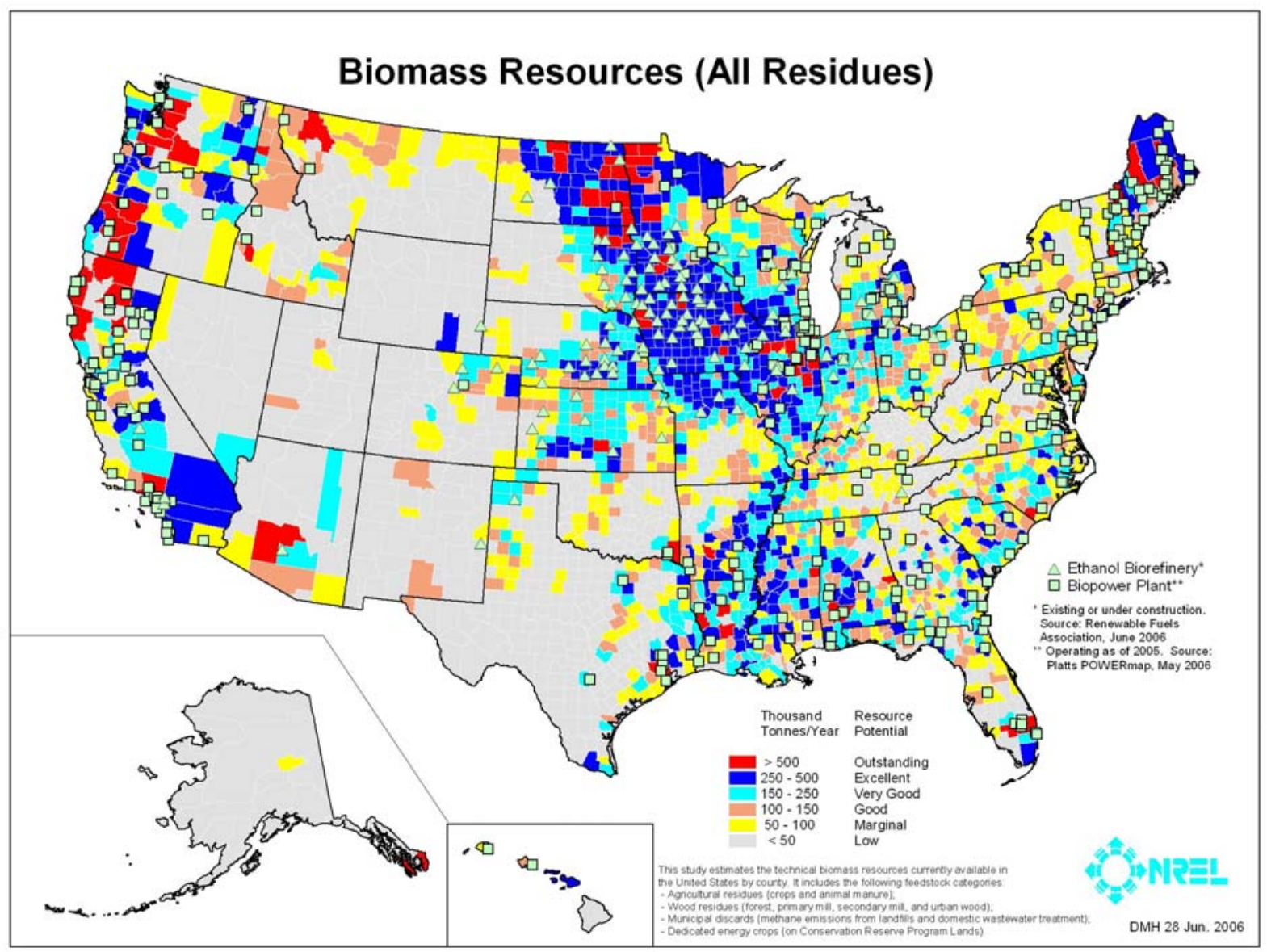

Figure 13: All biomass residue resource availability, with biorefineries and biopower plants that exist or are under construction.

\subsubsection{Screening Criteria for Biomass}

Screening criteria that are applied to identify high-potential sites for biomass applications are presented in Table 3. The three biomass applications addressed in this report share most of the same land-use exclusions as wind and CSP, so the sites shown in Figure 2 are the baseline sites for further screening for biomass applications. While it is conceivable to grow corn as a feedstock on certain excluded lands, it is prudent to eliminate these lands from consideration to avoid potential land-use conflicts. An exception to the land-use exclusions is that growing biomass is not subject to the $3 \mathrm{~km}$ buffer. The minimum parcel size of 50 acres for a dry mill corn ethanol or biopower plant supports only the plant with feedstock coming from off-site. 
Table 3: Land Considerations and Screening Criteria for Siting Biomass Operations on Limbo Lands

\begin{tabular}{|l|l|l|}
\hline \multicolumn{1}{|c|}{ Criteria } & \multicolumn{1}{|c|}{$\begin{array}{c}\text { Growing Corn as a Feedstock } \\
\text { for Biofuels }\end{array}$} & \multicolumn{1}{c|}{$\begin{array}{c}\text { Dry Mill Corn Ethanol Plant or } \\
\text { Biopower Plant }\end{array}$} \\
\hline Minimum Parcel Size & $>=200$ acres & $>=50$ acres \\
\hline Resource & $\begin{array}{l}\text { Crop residues }>=100,000 \\
\text { tonnes/yr }\end{array}$ & $\begin{array}{l}\text { Dry Mill Corn Ethanol Plant: Crop residues } \\
>=100,000 \text { tonnes/yr } \\
\text { Biopower plant: All residues }>=150,000 \\
\text { tonnes/yr }\end{array}$ \\
\hline Distance to Road & $<=50$ miles & $<=50$ miles \\
\hline $\begin{array}{l}\text { Distance to } \\
\text { Transmission }\end{array}$ & NA & $<=50$ miles \\
\hline
\end{tabular}

\subsubsection{Growing Corn as a Feedstock for Dry Mill Corn Ethanol Plant High-Potential Sites}

After applying land-use exclusions and minimum parcel size, 72 sites remain for further screening for growing corn as shown in Figure 14. After resource criteria and minimum distance to road have been applied, seven sites remain (see Figure 15) and can be considered as high-potential sites for growing corn as a feedstock for a dry mill corn ethanol plant:

- Koppers Co. Inc. (Oroville Plant), Oroville, California (Butte County)

- Louisiana-Pacific Corporation, Oroville, California (Butte County)

- Waite Park Wells, Waite Park, Minnesota (Stearns County)

- Pine Bend Sanitary Landfill, Dakota County, Minnesota (Dakota County)

- Fisher-Calo, La Porte, Indiana (La Porte County)

- Bayou Sorrel, Bayou Sorrel, Louisiana (Iberville Parish)

- Velsicol Chemical Corporation (Marshall Plant), Marshall, Illinois (Clark County) 


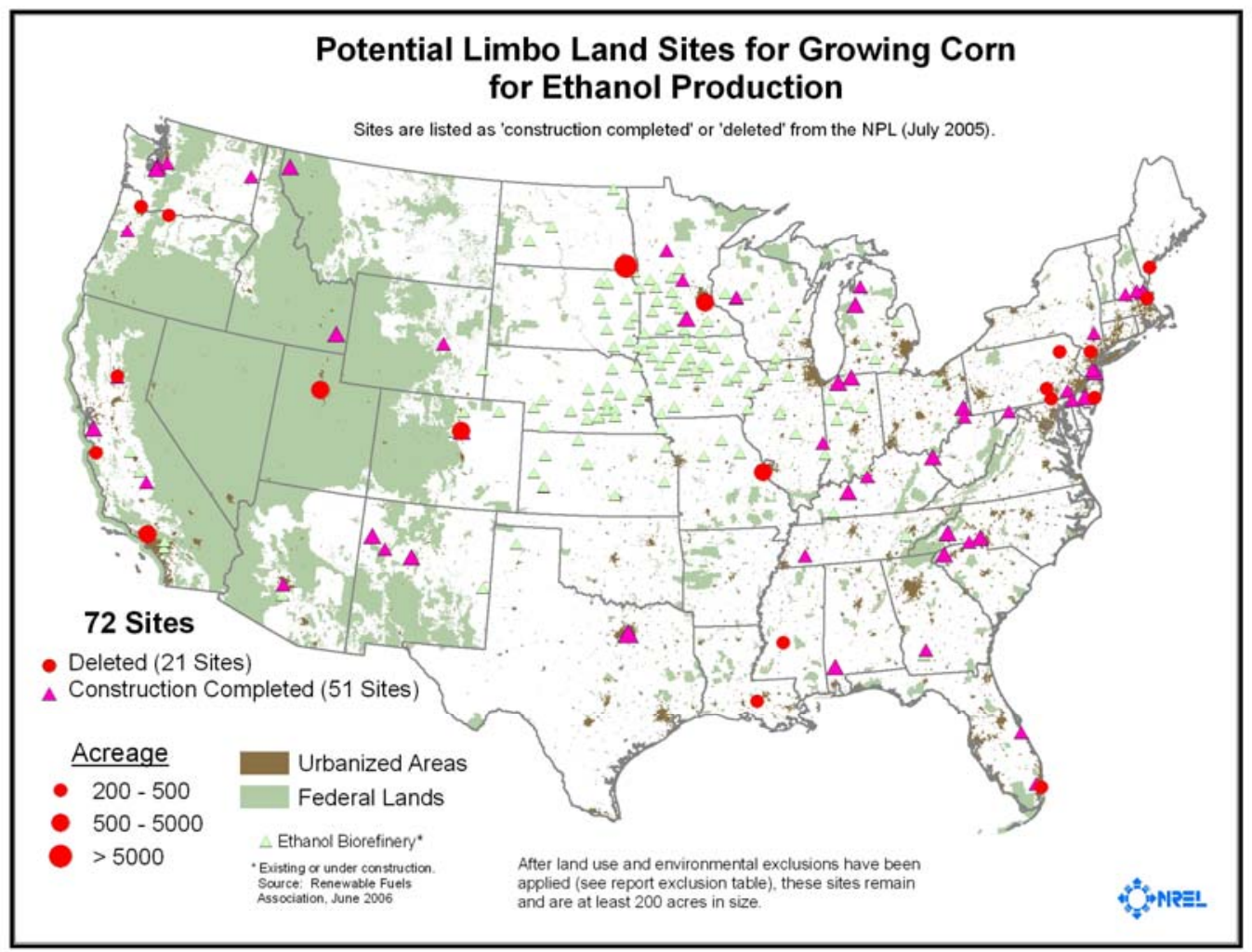

Figure 14: Sites that meet preliminary screening criteria for growing corn as a feedstock for biofuels, with biorefineries that exist or are under construction.

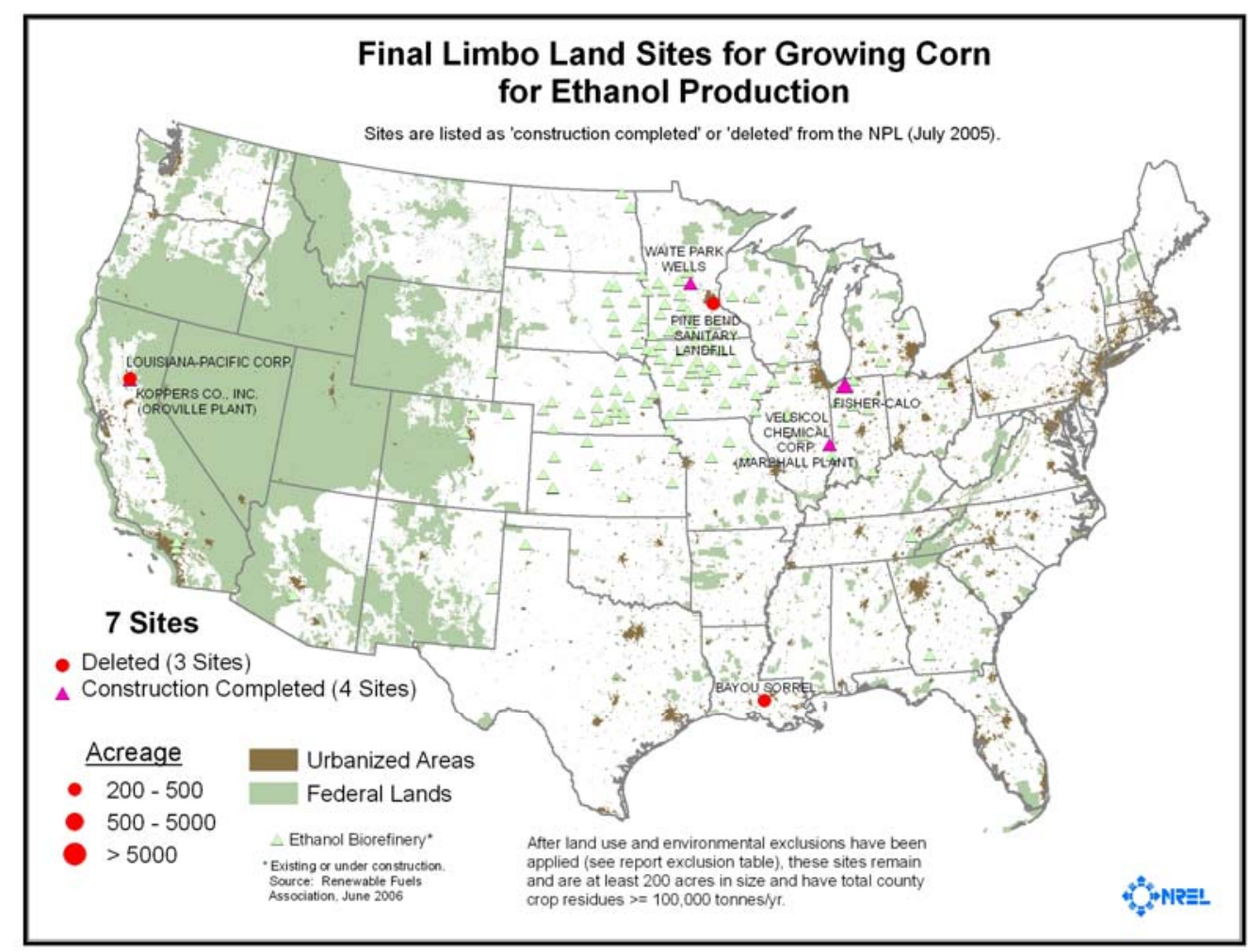

Figure 15: Final sites for growing corn as a feedstock for biofuels, with biorefineries that exist or are under construction. 


\subsubsection{Dry Mill Corn Ethanol Plant or Biopower Plant High-Potential Sites}

Similar criteria can be applied to a dry mill corn ethanol or biopower plant with the exception of the resource criteria. A dry mill corn ethanol plant requires minimum agricultural residue resource availability, while a biopower plant can consider all residues. After applying land-use exclusions $^{18}$ and minimum parcel size, 248 sites remain for further screening (see Figure 16). Once resource criteria and minimum distance to transmission and road have been applied, 17 sites are suitable for a dry mill corn ethanol plant or biopower plant, and 15 additional sites are suitable for a biopower plant only (see Figure 17) and can be considered as high-potential sites. These include:

Dry Mill Corn Ethanol Plant or Biopower Plant

- Big River Sand Co., Wichita, Kansas (Sedgwick County)

- Coalinga Asbestos Mine, Coalinga, California (Fresno County)

- Mid-America Tanning Co., Sergeant Bluff, Iowa (Woodbury County)

- Northwestern States Portland Cement Co., Mason City, Iowa (Cerro Gordo County)

- Bayou Sorrel, Bayou Sorrel, Louisiana (Iberville Parish)

- Louisiana-Pacific Corp., Oroville, California (Butte County)

- Pine Bend Sanitary Landfill, Dakota County, Minnesota (Dakota County)

- Electro-Coatings, Inc., Cedar Rapids, Iowa (Linn County)

- Galesburg/Koppers Co., Galesburg, Illinois (Knox County)

- Madison Metropolitan Sewerage District Lagoons, Blooming Grove, Wisconsin (Dane County)

- NCR Corp. (Millsboro Plant), Millsboro, Delaware (Sussex County)

- Pagel's Pit, Rockford, Illinois (Winnebago County)

- Verona Well Field, Battle Creek, Michigan (Calhoun County)

- Koppers Co. Inc. (Oroville Plant), Oroville, California (Butte County)

- Velsicol Chemical Corp. (Marshall Plant), Marshall, Illinois (Clark County)

- Waite Park Wells, Waite Park, Minnesota (Stearns County)

- Fisher-Calo, La Porte, Indiana (La Porte County)

Biopower Plant only

- Alcoa (Vancouver Smelter), Vancouver, Washington (Clark County)

- John Deere (Ottumwa Works Landfills), Ottumwa, Iowa (Wapello County)

- Lackawanna Refuse, Old Forge, Pennsylvania (Lackawanna County)

- Lee's Lane Landfill, Louisville, Kentucky (Jefferson County)

- M\&T Delisa Landfill, Asbury Park, New Jersey (Monmouth County)

- Munisport Landfill, North Miami, Florida (Miami-Dade County)

- Petersen Sand \& Gravel, Libertyville, Illinois (Lake County)

- Saco Tannery Waste Pits, Saco, Maine (York County)

- San Fernando Valley (Area 3), Glendale, California (Los Angeles County)

- Sand Creek Industrial, Commerce City, Colorado (Adams County)

- Southside Sanitary Landfill, Indianapolis, Indiana (Marion County)

\footnotetext{
${ }^{18}$ Land exclusions are applied for purposes of plant-siting considerations. Certain excluded lands can be sources for biomass residues used as a feedstock for biopower.
} 
- Taylor Borough Dump, Taylor Borough, Pennsylvania (Lackawanna County)

- Times Beach, Times Beach, Missouri (St. Louis County)

- Tulalip Landfill, Marysville, Washington (Snohomish County)

- York County Solid Waste and Refuse Authority Landfill, Hopewell Township, Pennsylvania (York County)

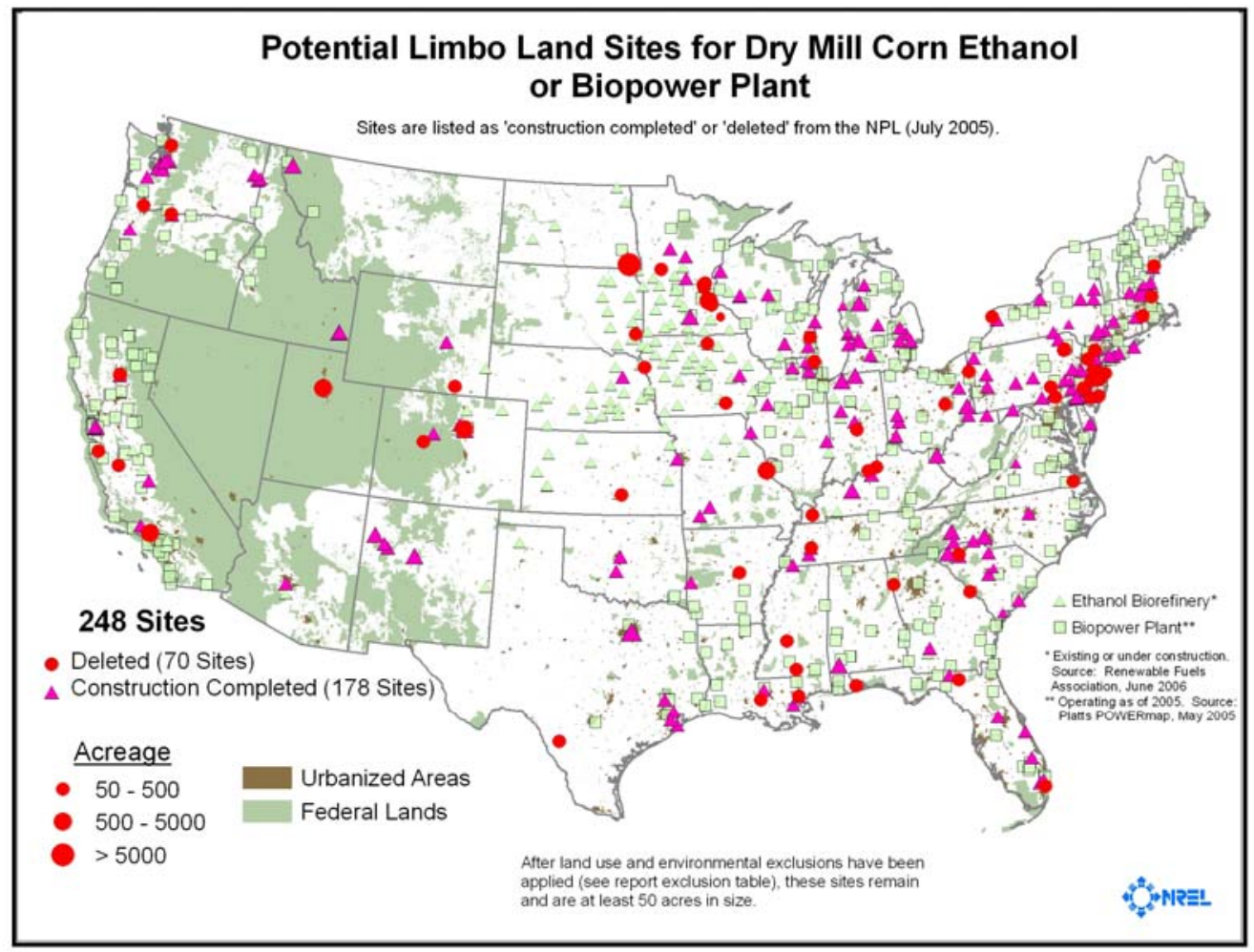

Figure 16: Sites remaining after applying preliminary screening criteria for dry mill corn ethanol and biopower plants, with biorefinery and biopower plants that exist or are under construction. 


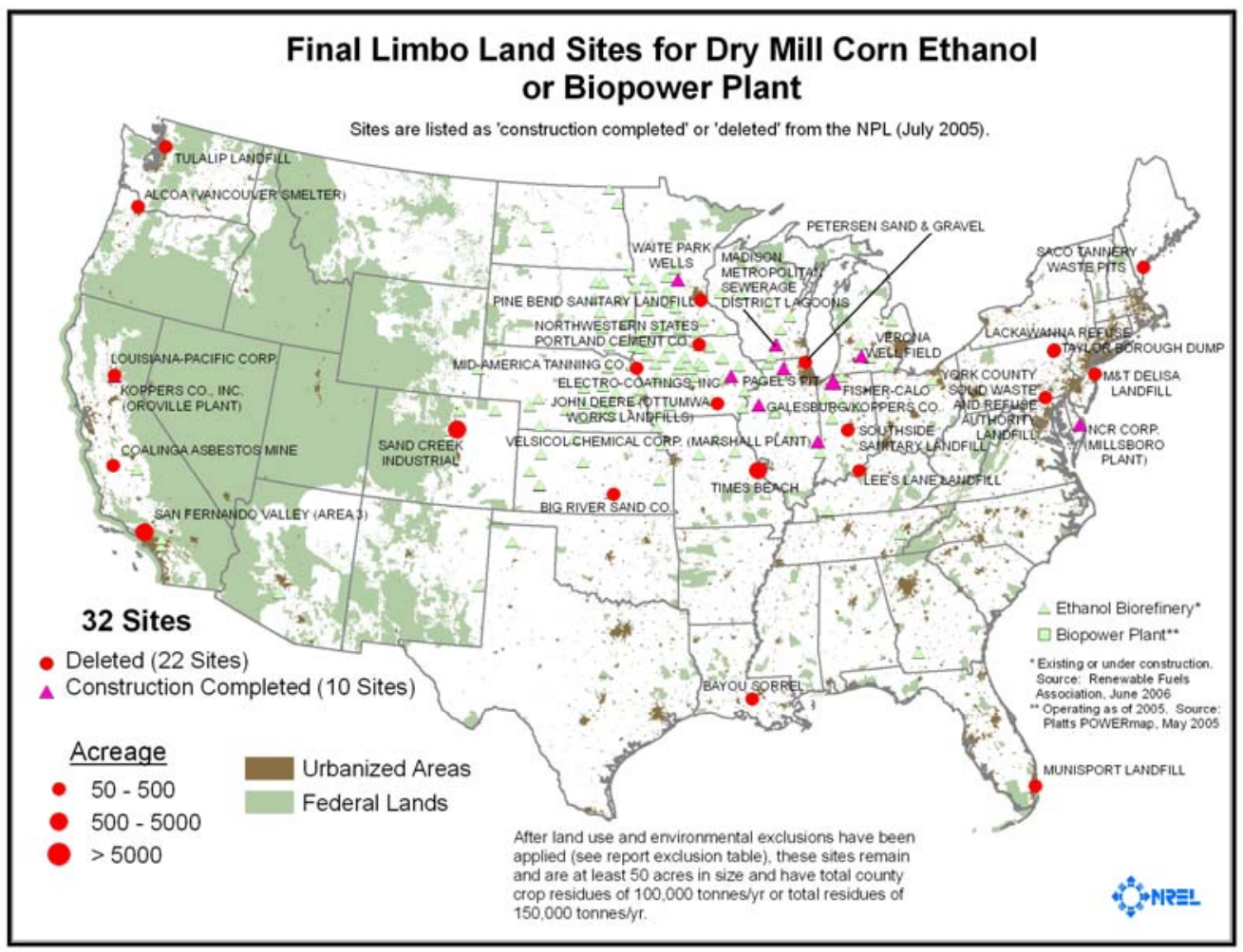

Figure 17: Final sites for dry mill corn ethanol and/or biopower plants, with biorefinery and biopower plants that exist or are under construction.

\subsection{Other Types of Limbo Lands - Brownfields and Abandoned Mine Lands}

There are numerous brownfields and abandoned mine lands throughout the United States. Resource screening issues associated with each category of Limbo Lands are discussed below.

\subsection{Brownfields}

Brownfields are abandoned, idled, or underused industrial and commercial facilities where expansion or reuse is complicated by real or perceived environmental contamination. Brownfields data quality varies from State to State and from EPA region to EPA region. Florida was selected as a case study on brownfields site screening because it has readily available brownfield data, including data for GIS coordinates and parcel size. High-potential sites can be determined for other States by using the process set forth for Florida. 


\subsubsection{Florida Brownfields}

Brownfields in Florida with the greatest potential for renewable energy reuse are identified in this section. Overall, $119^{19}$ brownfields in Florida were identified (see Figure 18). RETs considered for Florida are PV and biomass, because the wind resource and the solar resource for CSP in Florida are not adequate for consideration.

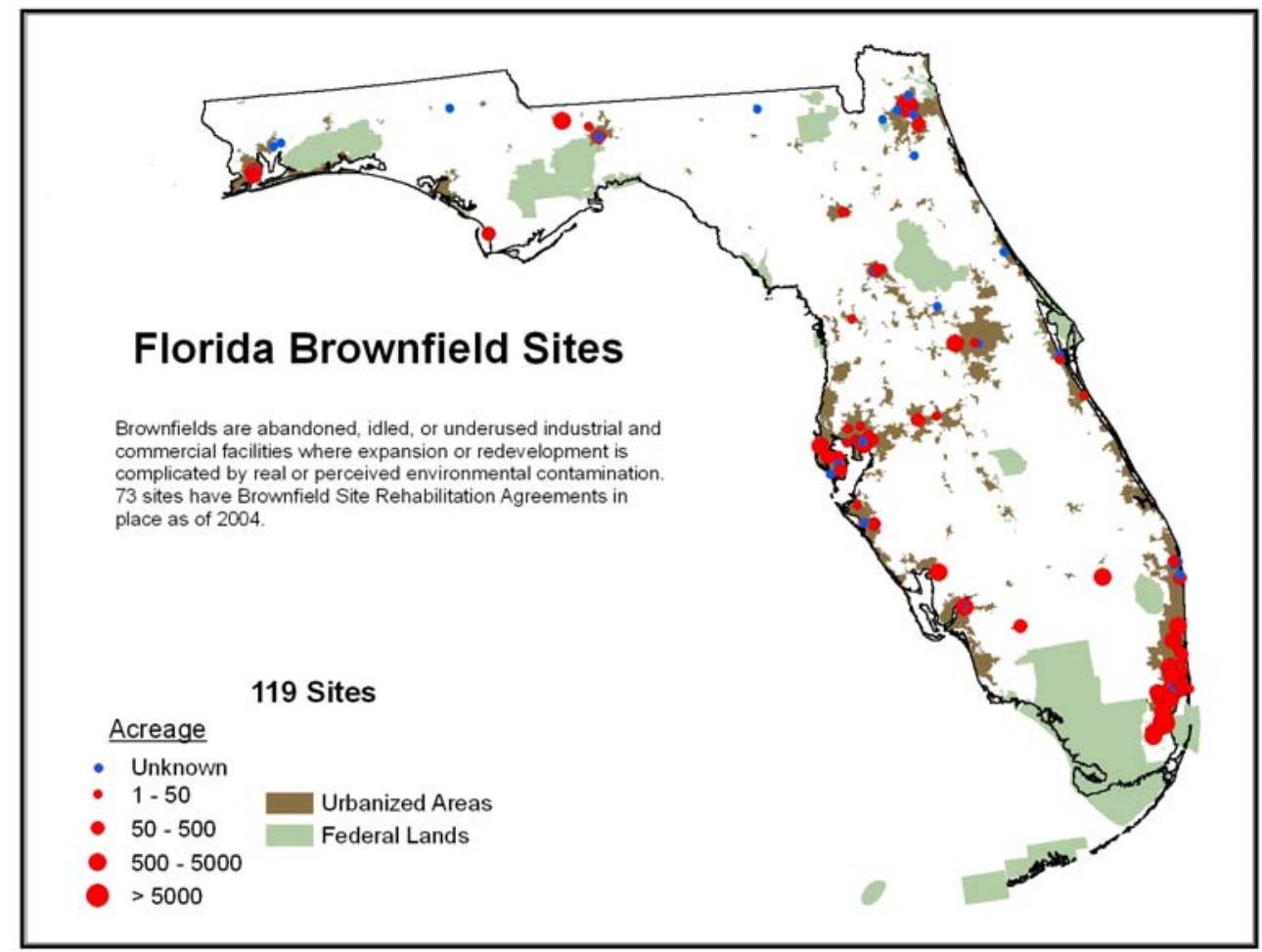

Figure 18: Brownfields in Florida.

\footnotetext{
${ }^{19}$ http://www.dep.state.fl.us/waste/categories/brownfields/default.htm downloaded on 6/28/2006.
} 


\subsubsection{PV in Florida}

All sites in Florida have sufficient resource for PV. The PV resource availability with brownfield sites is illustrated in Figure 19.

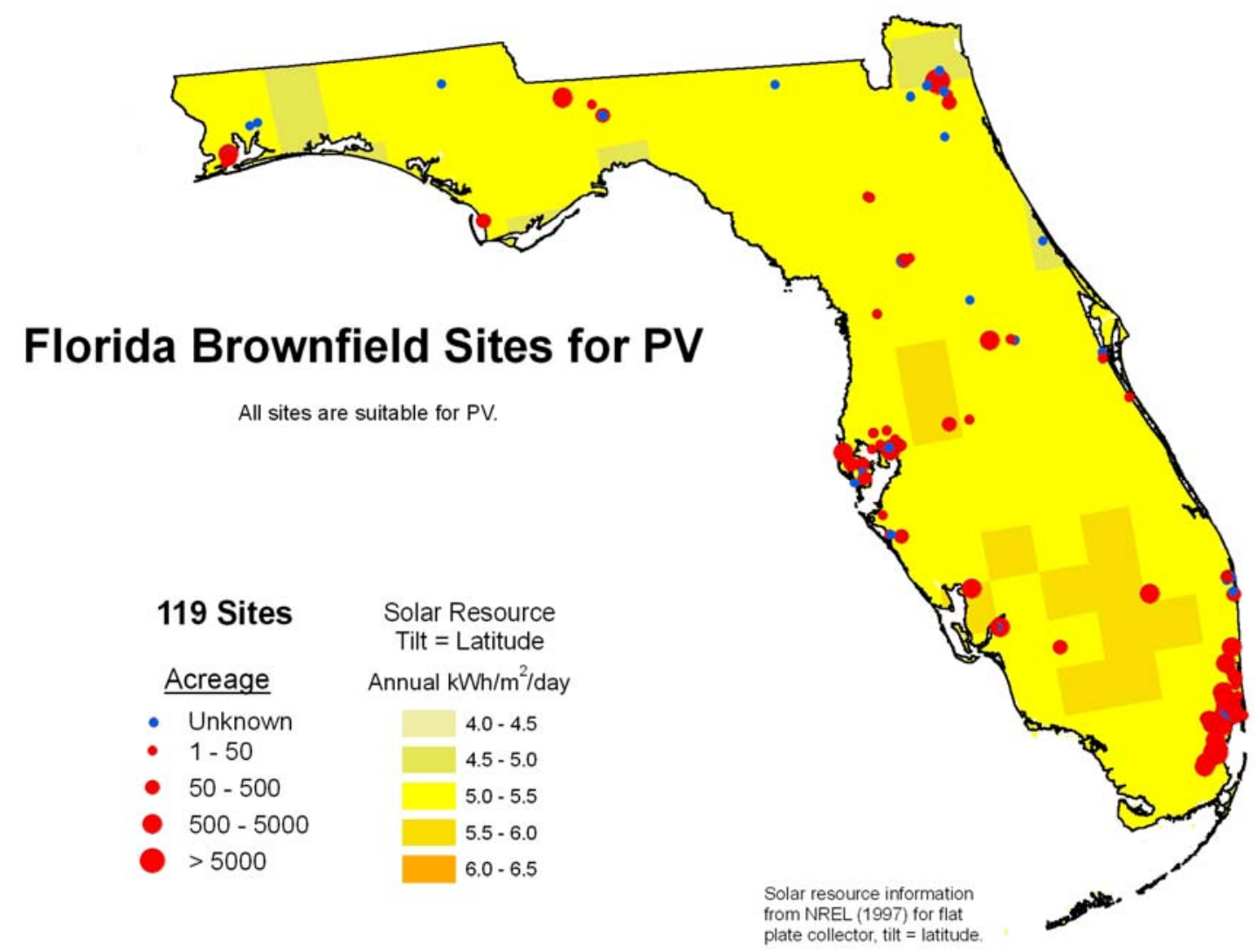

Figure 19: PV resource availability in Florida, with all brownfield sites. 


\subsubsection{Biomass in Florida}

Florida has ample resources for biomass applications. This analysis considers potential brownfield sites for a biopower plant, a dry mill corn ethanol plant, and growing corn as a feedstock for a dry mill corn ethanol plant. Figure 20 illustrates the agricultural biomass resource availability in Florida with all the brownfield sites, while Figure 21 shows all biomass residue resource availability.

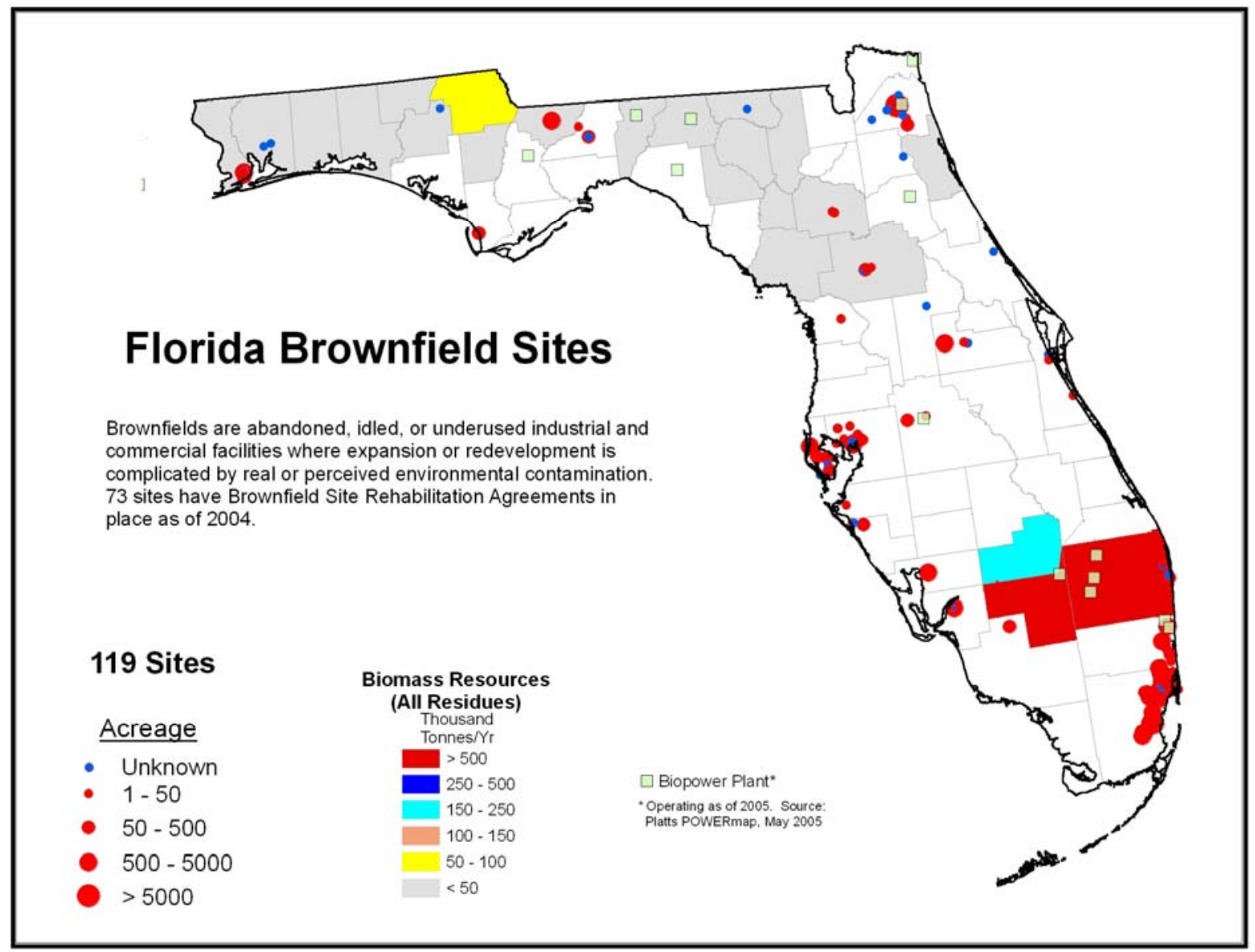

Figure 20: Agricultural biomass resource availability in Florida, with all brownfield sites. 


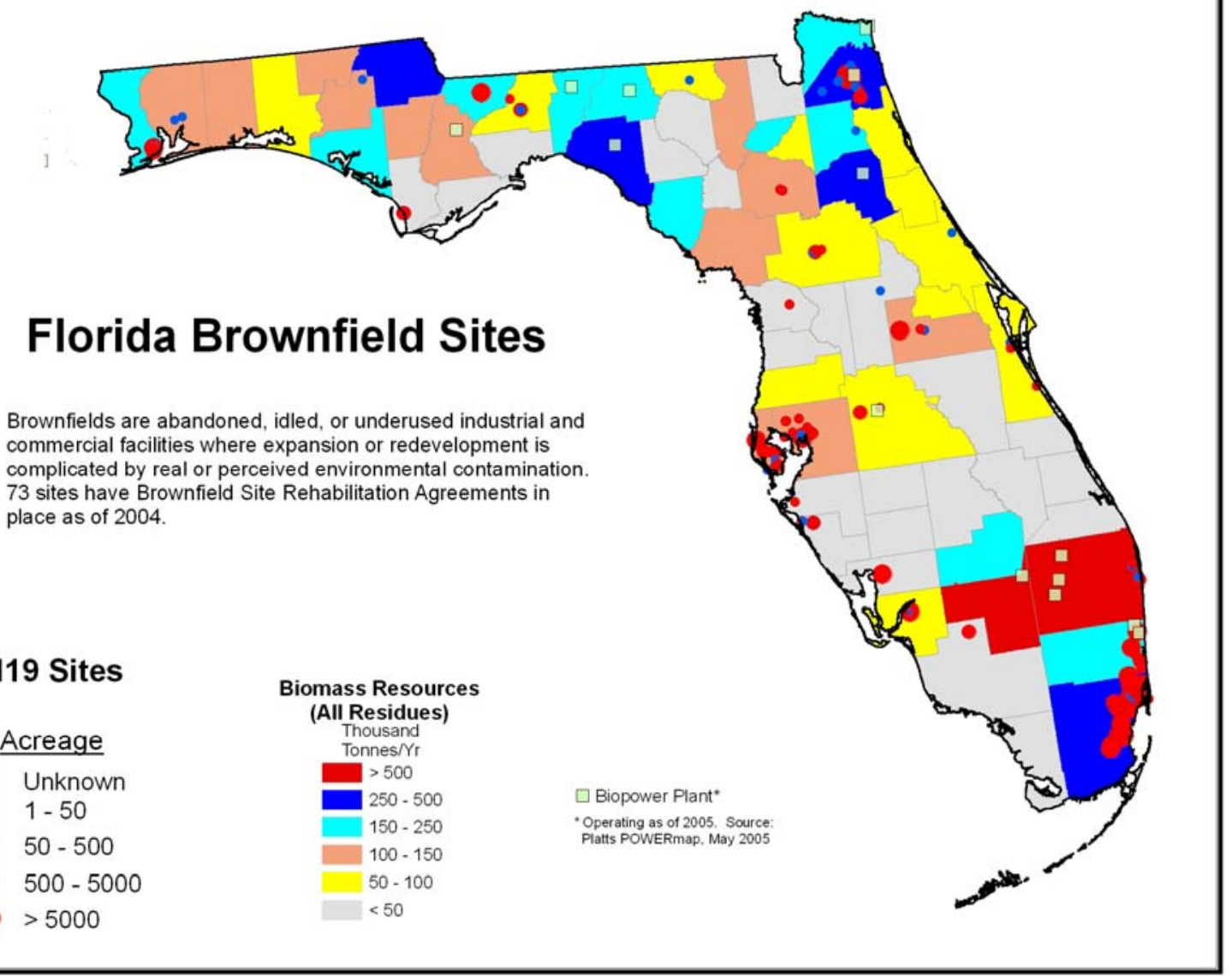

Figure 21: Biomass residue availability of all residues in Florida, with all brownfield sites.

After land considerations and screening criteria (identified in Table 3) are applied to brownfields in Florida, 25 sites remain as high-potential sites (see Figure 22) as listed below. All 25 sites meet the criteria for a biopower plant. Some sites are also suitable for a dry mill corn ethanol plant, including Belle Glade, former Palm Beach Lakes Golf Course, and Lake Worth (a closed municipal landfill). Belle Glade is the only site suitable for growing corn as a feedstock for biofuels, given the added screening criteria of at least 200 acres and that it is within 50 miles of an existing biorefinery. 
Florida Brownfield Sites for Biopower Plant

- Former Palms Beach Lakes Golf Course ${ }^{\mathrm{i}}$

- Belle Glade Brownfield Area,ii

- Lake Worth Closed Municipal Landfilli

- Pompano Beach Northwest Area

- US 441/SR 7 Corridor

- Liberia/Oakwood Hills Area

- Carol City Area

- Dade-Opa-Locka Area

- Central Miami Area

- Miami Area

- Opa-Locka Area

- Pilot Project Area

- Palafox Corridor Redevelopment Area

${ }^{\mathrm{i} A}$ Also suitable for a dry mill corn ethanol plant.

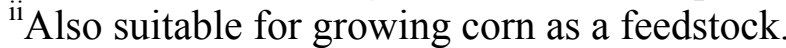

- Richmond Heights area

- Perrine area

- South Miami

- South Dade

- Homestead CRA area

- Redlands/Leisure City area

- Beacons Lake Brownfield area

- Model City/Brownsville

- Sweetwater A Area

- Sweetwater B Area

- Sweetwater C Area

- Quincy Area

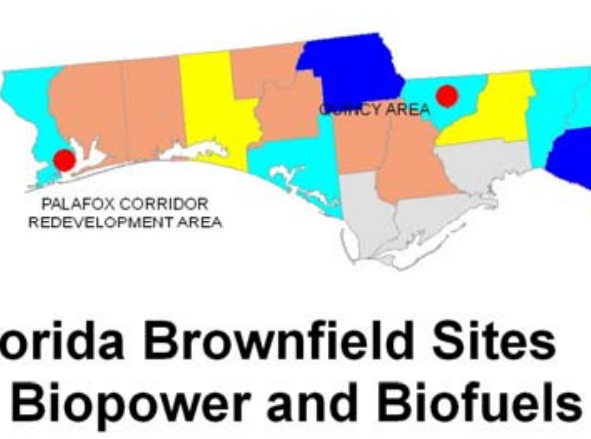

Sites are within 50 miles of major roads, and 10 miles of major transmission lines. These sites have county total biomass residues $>=150,000$ tonnes/yr or county total crop residues $>=100,000$ tonnes/yr, and are known to be 50 acres or larger in size.

All 25 sites are suitable for a biopower plant. The following sites are also suitable for a dry mill corn ethanol plant: Belle Glade, former Palm Beach Lakes Golf Course, and Lake Worth Closed Municipal Landfill. Belle Glade is the only site identified as being suitable for growing corn for biofuels, given the added screening criteria of $>=200$ acres and within 50 miles of an existing biorefinery.

\begin{tabular}{cc}
25 Sites & $\begin{array}{c}\text { Biomass Resources } \\
\text { (All Residues) } \\
\text { Thousand } \\
\text { Tonnes/Yr }\end{array}$ \\
Acreage & $>500$ \\
\hline $50-200$ & $250-500$ \\
$-200-500$ & $150-250$ \\
$-500-5000$ & $100-150$ \\
$>5000$ & $50-100$ \\
& $<50$
\end{tabular}

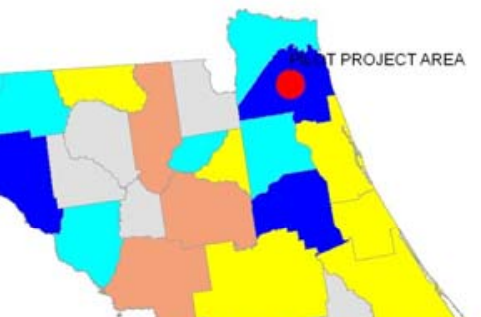

Florida Brownfield Sites for Biopower and Biofuels 


\subsection{Abandoned Mine Lands}

Abandoned mine land (AML) data is available through a few sources, two of which are discussed here. The data mapped in Figure 23 is from an inventory called Abandoned Mine Lands Inventory System (AMLIS) administered by the Department of Interior's Office of Surface Mining (DOI-OSM) ${ }^{20}$ There are more than 39,000 sites included in this inventory. Limitations associated with this data, such as lack of data on parcel size and status of site release, do not necessarily lend themselves to the GIS screening process set forth in this report. The inventory does identify types of problems at the site, such as clogged streams, dangerous conditions, and hazardous gases, but a more definitive indication of cleanup status is required to narrow down high-potential sites. Another source for AML data is EPA's AML CERCLIS Inventory gathered from CERCLIS data and in a limited manner from EPA regional staff. ${ }^{21}$ This inventory consists of 562 sites compiled as of 2002 by EPA's AML team. ${ }^{22}$ A primary distinction between the two is that AMLIS focuses on abandoned coal mines, while EPA's AML CERCLIS inventory addresses abandoned hard rock mines.

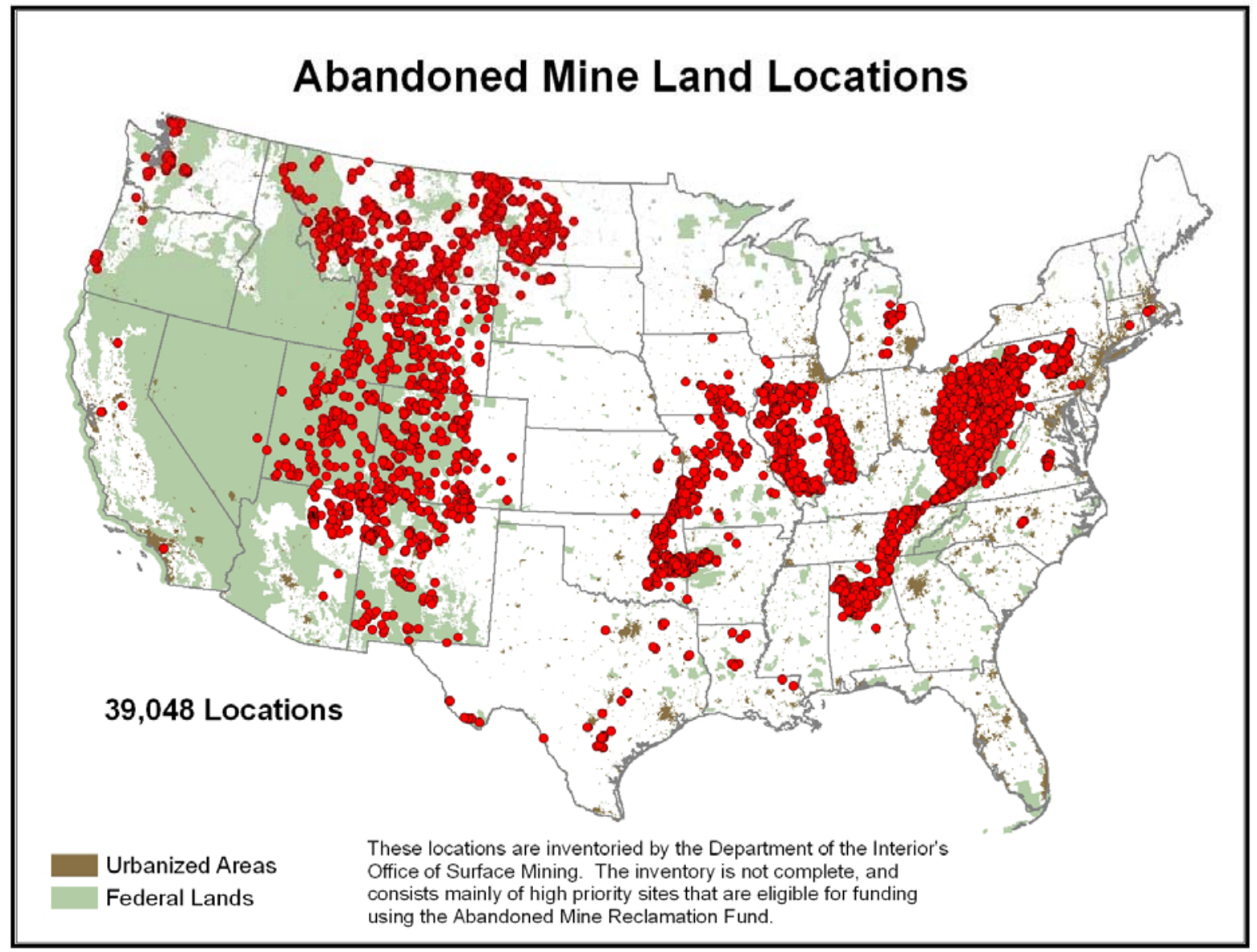

Figure 23: Abandoned mine land (AML) locations.

\footnotetext{
${ }^{20} \mathrm{http}: / /$ www.osmre.gov/aml/inven/zintroin.htm

${ }^{21} \mathrm{http}: / /$ www.epa.gov/superfund/programs/aml/tech/appena.pdf

22 http://www.epa.gov/superfund/programs/aml/amlsite/nonnpl.htm
} 


\subsection{Recommendations and Conclusions}

This study provides a geographic screening of Limbo Lands with high potential for renewable energy technology redevelopment. RETs considered were wind, solar, and biomass. This screening process illustrates that there are several ideal sites for each RET. Given the rigorous geographic screening process for the sites, those sites identified meet the criteria for serious consideration of redevelopment with RETs. Further investigation of each site is required for assessment of economic feasibility and community, and developer interest. Assuming there is interest in a particular site, that site owner could be contacted to pursue the RET redevelopment opportunity.

Data availability would definitely improve the study. The NPL provides a comprehensive listing of sites for initial investigation, but does not cover all types of Limbo Lands. It is unlikely that all types would be presented in one data site, but multiple sources could be combined to conduct a comprehensive geographic (GIS) screening. For data to be useful for this geographic screening, it must include parcel size, geographic locator information, and status of cleanup at the site.

There is excellent potential for RETs to be used as part of the redevelopment strategy for Limbo Lands. RETs not only can play a role in redevelopment, but can also be used to power remediation efforts and monitoring requirements. Further study to identify specific renewable energy applications most suitable to remediation and monitoring activities, and to evaluate resource considerations, would be required to identify the most promising opportunities. 


\section{Appendix A - An Assessment of RET Potential at a Former Mine in Beatty, Nevada}

An assessment of a former mine in Beatty, Nevada, is an example of how NREL evaluated a "Limbo Land" site for potential renewable energy development.

Beatty Economic Development Corporation, which owns 82 acres from the Barrick-Bullfrog mine closure, wanted to pursue sustainable economic growth opportunities, with a primary objective of producing and exporting alternative energy from Beatty.

A county grant provided funds for redevelopment guidance, engaging stakeholders, and support for technical expertise. This resulted in an action plan for the Beatty Mine Scarred Land Redevelopment project, which included an effort to conduct an alternative energy feasibility study.

Some of the stakeholders for the project include the Beatty Economic Development Corporation, the Beatty Town Advisory Board, the Nevada State Energy Office, the EPA Brownfield Programs, and Beatty residents.

As part of DOE's national laboratory support, NREL provided geographical information system (GIS) screening for this high-potential site. This evaluation looked at land exclusion, distance to transmission and major roads, and technology assessment. Using an analysis approach similar to one done for the Bureau of Land Management (BLM), NREL determined that Beatty had a high potential for solar and wind resources.

One of the proposed technologies was parabolic trough solar power as a resource for an electricgeneration facility. Some of the most attractive features included a high direct normal solar resource, an already "disturbed" flat land parcel, a viable water resource (steam turbogenerator), utility demand for renewable energy, and proximity to a transmission grid with good capacity.

NREL recommended consideration of an economic/technical feasibility analysis for a 10-20 MW solar plant, which would provide local access and export potential. However, there could be issues for a private developer with the liability for impacts on a contaminated site and the ability to purchase a long-term power purchase agreement. It was also determined that a developer would need to address and resolve potential impacts on Air Force training operations in the area.

The analysis also looked at factors such as employment, personal income, and the gross State product for the concentrating solar power trough facility in Nevada. For instance, NREL estimated that the construction phase (over two years) could add 250 new jobs in the first year, with about 200 of those retained each year.

NREL also looked at wind power as a possibility for development. The site has a high wind resource on ridges around the mine site and would be part of a proactive Bureau of Land Management wind energy development program on public lands. It also would have proximity to a transmission grid with good capacity. 
Issues for wind power development were similar to those for solar power. The application would require an environmental assessment for development, a project review to see how it would affect Air Force training operations, and a need to acquire the power purchase agreement.

The NREL analysis recommended considering a 10-20 MW wind farm, which could have positive economic impacts for employment, sales taxes, and personal income. 


\section{Appendix B - PV and CSP Screening Criteria for BLM and USFS Evaluation by NREL}

Table B-1: Screening Criteria Developed by NREL for PV and CSP Resources for Evaluations Conducted on Behalf of BLM and USFS

\begin{tabular}{|c|c|c|c|}
\hline Criterion & BLM - PV ${ }^{i}$ & BLM - CSPii & $\begin{array}{c}\text { USFS - PV and } \\
\text { CSP }^{\mathrm{iii}}\end{array}$ \\
\hline Resource & $\begin{array}{l}>=5 \mathrm{kWh} / \mathrm{m} 2 / \text { day } \\
\text { annual average tilt } \\
=\text { latitude collector }\end{array}$ & $\begin{array}{l}>=5 \mathrm{kWh} / \mathrm{m} 2 / \text { day } \\
\text { annual average } \\
\text { direct normal } \\
\text { collector (near term } \\
>=6 \mathrm{kWh} / \mathrm{m} 2 / \text { day) }\end{array}$ & $\begin{array}{l}>=5 \mathrm{kWh} / \mathrm{m} 2 / \text { day } \\
\text { annual average } \\
\text { (one-axis tracking } \\
\text { for PV and direct } \\
\text { normal for CSP) }\end{array}$ \\
\hline Slope & $<5 \%$ & $\begin{array}{l}<5 \% \text { (near term } \\
\text { less than } 1 \%)\end{array}$ & $\begin{array}{l}<5 \% \text { (ideally less } \\
\text { than } 1 \% \text { ) }\end{array}$ \\
\hline $\begin{array}{l}\text { Distance to } \\
\text { Transmission }\end{array}$ & $\begin{array}{l}<50 \text { miles to } 115- \\
345 \mathrm{kV} \\
\text { transmission lines }\end{array}$ & $\begin{array}{l}<50 \text { miles to } 115- \\
345 \mathrm{kV} \\
\text { transmission lines }\end{array}$ & $\begin{array}{l}<25 \text { miles of } 69- \\
345 \mathrm{kV} \text { lines }\end{array}$ \\
\hline Distance to Road & NA & $\begin{array}{l}<50 \text { miles to road } \\
\text { or railroad }\end{array}$ & $\begin{array}{l}<25 \text { miles to } \\
\text { graded roads }\end{array}$ \\
\hline $\begin{array}{l}\text { Minimum Parcel } \\
\text { Size }\end{array}$ & NA & 40 acre & 40 acre \\
\hline Land Exclusions & $\begin{array}{l}\text { National } \\
\text { monuments, } \\
\text { national } \\
\text { conservation areas, } \\
\text { wilderness areas } \\
\text { and wilderness } \\
\text { study areas } \\
\end{array}$ & $\begin{array}{l}\text { National } \\
\text { monuments, } \\
\text { national } \\
\text { conservation areas, } \\
\text { wilderness areas } \\
\text { and wilderness } \\
\text { study areas } \\
\end{array}$ & $\begin{array}{l}\text { Inventoried } \\
\text { Roadless Areas } \\
\text { and Specially } \\
\text { Designated Areas }\end{array}$ \\
\hline
\end{tabular}




\section{Appendix C - Wind Screening Criteria for Evaluation for BLM and USFS by NREL}

Table C-1: Screening Criteria Developed by NREL for Wind Resource for Evaluations Conducted on Behalf of BLM and USFS

\begin{tabular}{|c|c|c|c|}
\hline Criterion & $\begin{array}{l}\text { Wind Electric } \\
\text { Potential }\end{array}$ & BLM $^{\mathrm{i}}$ & USFS ${ }^{\mathrm{ii}}$ \\
\hline Resource & $\begin{array}{l}>=\text { class } 4, \text { with } \\
\text { occasional class } 3\end{array}$ & $\begin{array}{l}>=\text { class } 3 \text { annual } \\
\text { average (class } 4+ \\
\text { for near term) }\end{array}$ & $\begin{array}{l}>=\text { class } 3 \text { annual } \\
\text { average (class } 4+ \\
\text { for near term) }\end{array}$ \\
\hline Slope & $\begin{array}{l}<20 \% \text { on high } \\
\text { resolution wind } \\
\text { resource datasets }\end{array}$ & $\begin{array}{l}<20 \% \text { on high } \\
\text { resolution wind } \\
\text { resource datasets }\end{array}$ & $\begin{array}{l}<20 \% \text { on high } \\
\text { resolution wind } \\
\text { resource datasets }\end{array}$ \\
\hline $\begin{array}{l}\text { Distance to } \\
\text { Transmission }\end{array}$ & $\begin{array}{l}<25 \text { miles to } 69- \\
345 \mathrm{kV} \text { lines }\end{array}$ & $\begin{array}{l}<25 \text { miles to } 69- \\
345 \mathrm{kV} \text { lines }\end{array}$ & $\begin{array}{l}<25 \text { miles to } 69- \\
345 \mathrm{kV} \text { lines }\end{array}$ \\
\hline Distance to Road & $\begin{array}{l}<25 \text { miles to } \\
\text { graded roads }\end{array}$ & $\begin{array}{l}<50 \text { miles to } \\
\text { graded roads }\end{array}$ & $\begin{array}{l}<25 \text { miles to } \\
\text { graded roads }\end{array}$ \\
\hline $\begin{array}{l}\text { Distance to Major } \\
\text { Urban Area }\end{array}$ & $>3 \mathrm{~km}$ & & $>3 \mathrm{~km}$ \\
\hline $\begin{array}{l}\text { Minimum Parcel } \\
\text { Size }\end{array}$ & $\begin{array}{l}\text { Density analysis } \\
\text { after all the } 100 \% \\
\text { exclusions are } \\
\text { applied }(5 \mathrm{~km} 2 \text { of } \\
\text { class } 3 \text { or greater } \\
\text { resource within the } \\
\text { surrounding } 100 \\
\text { km2) }\end{array}$ & & \\
\hline Land Exclusions & $\begin{array}{l}\text { See Wind Electric } \\
\text { Potential Land } \\
\text { Exclusions } \\
\text { description below }\end{array}$ & $\begin{array}{l}\text { National } \\
\text { monuments, } \\
\text { national } \\
\text { conservation areas, } \\
\text { wilderness areas } \\
\text { and wilderness } \\
\text { study areas }\end{array}$ & $\begin{array}{l}\text { Inventoried } \\
\text { Roadless Areas } \\
\text { and Specially } \\
\text { Designated Areas }\end{array}$ \\
\hline \multicolumn{4}{|c|}{$\begin{array}{l}\text { Detailed Land Exclusions } \\
\text { In estimating wind electric potential, in addition to the screening criteria in the above table, the following } \\
\text { land exclusion criteria are applied: } \\
\text { - } 100 \% \text { exclusion for urban, water and wetlands } \\
100 \% \text { exclusion of federal lands with any type of special designation such as wilderness, } \\
\text { monument, national battlefield, etc. (not including national grasslands) } \\
50 \% \text { exclusion of remaining FS and DOD lands } \\
100 \% \text { of state and private environmentally sensitive lands where that data was available. } \\
\text { (Generally GAP } \text { Gii land stewardship data is used, with the highest protection level excluded } \\
100 \% \text {, and the second highest level excluded } 50 \% \text {.) } \\
\text { - All } 100 \% \text { excluded areas except for water bodies expanded by } 3 \mathrm{~km} \text { along perimeter } \\
\text { - } 50 \% \text { exclusion of non-ridge crest forest }\end{array}$} \\
\hline \multicolumn{4}{|c|}{\begin{tabular}{|l|} 
'Bureau of Land Management \\
"Forest Service \\
iii'Gap Analysis Program \\
\end{tabular}} \\
\hline
\end{tabular}

